\title{
The bi-decadal rainfall cycle, Southern Annular Mode and tropical cyclones over the Limpopo River Basin, southern Africa
}

\author{
Published in Climate Dynamics: \\ Malherbe J, Landman WA and Engelbrecht FA. 2014. The bi-decadal rainfall cycle, \\ Southern Annular Mode and tropical cyclones over the Limpopo River Basin, \\ southern Africa. Climate Dynamics. 42:3121-3138. doi:10.1007/s00382-013- \\ 2027-y.
}

\begin{abstract}
The association between bi-decadal rainfall variability over southern Africa and the rainfall contributed by tropical cyclonic systems from the Southwest Indian Ocean (SWIO) provides a potential means towards understanding decadal-scale variability over parts of the region. A multi-decadal period is considered, focusing on the anomalous tropospheric patterns that induced a particularly wet 8-year long sub-period over the Limpopo River Basin. The wet sub-period was also characterized by a larger contribution to rainfall by tropical cyclones and depressions. The findings suggest that a broadening of the Hadley circulation underpinned by an anomalous anticyclonic pattern to the east of southern Africa altered tropospheric steering flow, relative vorticity and moisture contents spatially during the subperiod of 8 years. These circulation modulations induced enhanced potential for tropical systems from the SWIO to cause precipitation over the Limpopo River Basin. The same patterns are also conducive to increasing rainfall over the larger subcontinent, therefore explaining the positive association in the bi-decadal rainfall cycle and rainfall contributed by tropical cyclonic systems from the SWIO. The regional circulation anomalies are also explained in hemispheric context, specifically in relation to the Southern Annular Mode, towards understanding variation over other parts of the Southern Hemisphere at this time scale.
\end{abstract}

\section{Introduction}

Rainfall that occurs in association with landfalling tropical cyclones and depressions (hereafter referred to as tropical systems) from the Southwest Indian Ocean (SWIO) over the Limpopo River Basin in southern Africa vary at a bi-decadal time scale, in phase with a similar cycle noted earlier in the rainfall time series over subtropical southern Africa (Malherbe et al. 2012). Known as the Dyer-Tyson cycle (Dyer and Tyson 1977), the 18-20year (bi-decadal) cycle has been shown to be a feature of southern African rainfall over a period of at least 600 years (Tyson et al. 2002). The ENSO-rainfall relationship in the region (Ropelewski and Halpert 1987, Nicholson and Kim 1997, Reason et al. 2000, Reason et al. 
2005) is altered by this bi-decadal variation in the regional climate with El Niño and La Niña seasons being wetter/drier during multi-year epochs of above-normal/below-normal rainfall (Kruger 1999). The importance of hemispheric-scale anomalies associated with this cycle is implicated by teleconnections with glacial variation over New Zealand (Tyson et al. 1997) since the early part of the $20^{\text {th }}$ century.

Mason and Jury (1997) reviewed regional circulation anomalies associated with climatic variability in the southern African region. These include for wetter periods positive anomalies in the geopotential heights of the lower to mid-troposphere over the mid- to subtropical latitudes, especially towards the southwest of the subcontinent over the Atlantic Ocean, and towards the south (Miron and Tyson 1984, Preston-Whyte and Tyson 2000). Positive anomalies throughout the troposphere towards the southeast and east over the Indian Ocean are also associated with wet conditions (Jury 1996, Jury and Nkosi 2000, Hofmeyer and Gouws 1964, Washington and Preston 2006). This association results from increased easterly flow causing enhanced westward and southwestward advection of moist air from the SWIO (D’Abreton and Lindesay 1993, Matarira and Jury 1992, Jury 1996) and concurrent increase in barotropic instability responsible for a higher frequency and growth rate of tropical disturbances (Mulenga et al. 2003). Furthermore, there is a southward shift in the occurrence of westerly winds (including the Jet stream at $200 \mathrm{hPa}$ ) that would advect dry air from the Atlantic Ocean towards the southern parts of the subcontinent if located further north (D’Abreton and Lindesay 1993, Richard et al. 2001, Mulenga et al. 2003). The anticyclonic anomaly to the southeast and east of southern Africa that characterizes wet summer seasons is replaced by a cyclonic anomaly in the same area during dry conditions (Richard et al. 2001). This is the case for non-ENSO-related droughts well as for ENSO-related droughts (Mulenga et al. 2003, Pezza and Ambrizzi 2003, Richard et al. 2000). To the east of the subcontinent during ENSO warm events, vorticity advection by storms in the westerlies tracking further north is responsible for the development of a Rossby wave to the east of southern Africa (Cook 2000), which may result in anomalously low rainfall over the subcontinent.

The bi-decadal geopotential anomalies over the oceanic regions surrounding southern Africa can be attributed to the influence of planetary standing waves 1 and 3 (Trenberth 1980, Tyson 1981, Jury 1996) which may be modulated by large-scale SST anomalies in the Eastern Pacific (Hurrell and van Loon 1994). The association with planetary standing waves indicates a mid- to high latitude influence on the regional subtropical climate variability (Mason and Jury 1997). The principal mode of variability between the extratropics and high latitudes in the Southern Hemisphere (SH) is the Southern Annular Mode (SAM - Limpasuvan and Hartmann 2000). Positive pressure anomalies over the mid-latitudes throughout the troposphere are more prominent during the positive phase of the SAM. Hence, a positive association between rainfall over much southeastern southern Africa and the SAM exists (Gillett et al. 2006). This positive association of SAM with rainfall is also present at subtropical latitudes of Australia and South America, whilst a negative relationship holds for the southern parts of South America and New Zealand (Gillet et al. 2006) as well as the winter rainfall region of southern Africa (Reason and Rouault 2005). While it is influenced by ENSO (L'Heureux and Thompson 2006, Gong et al. 2010), the SAM is also positively (negatively) correlated to ENSO cold (warm) event teleconnections towards the high southern latitudes (Fogt et al. 2011).

While it is influenced by Gong et al. 2010), the SAM is also positively (negatively) ENSO (L'Heureux and Thompson, 2006, correlated to ENSO cold (warm) event teleconnections towards the high southern latitudes (Fogt et al. 2011).

A higher frequency of tropical systems tracking into the interior over the Limpopo River Basin was responsible for an increase in major flood events (e.g. Crimp and Mason 1999, Dyson and van Heerden 2002, Reason and Keibel 2004) during the 1995-2003 period 
(Malherbe et al. 2012). This was consistent with a predicted increase in rainfall during this period as per the aforementioned bi-decadal rainfall variation (Dyer and Tyson 1977). Largescale circulation anomalies such as the Pacific-Decadal Oscillation and Atlantic Multidecadal Oscillation have been shown to cause decadal-scale variability in the tracks of tropical cyclones over the Atlantic and Pacific Oceans (Chu 2002, Liu and Chan 2008, Matsuura et al. 2003, Kubota and Chan 2009, Goldenberg et al. 2001). This happens through forcing of variables important to tropical cyclone tracks such as steering flow (defined to be the weighted average flow between $850 \mathrm{hPa}$ and $200 \mathrm{hPa}$ ), moisture availability, SSTs, largescale vorticity as well as vertical wind shear (Chan 1985, Holland 1982, 1984, Becker et al. 2010). ENSO also affects the tracks of tropical cyclones over all ocean basins through the remote forcing of genesis parameters and circulation patterns (Gray 1984, 1988, Chan 1985, Vitart et al. 1999, Camargo et al. 2007). In the SWIO towards the north of $20^{\circ} \mathrm{S}$ in particular, large-scale lower-level vorticity becomes anomalously positive in response to ENSO, diminishing dynamic potential for the development of tropical cyclones in the region (Vitart et al. 1999). In general over the SWIO, a southward shift of upper air westerlies, increased easterly trade winds and a strengthened Hadley circulation are characteristic of summers with more tropical cyclones (Jury 1993). Furthermore, an anomalously strong easterly flow to the east of the subcontinent in the subtropics increases the chance of tropical cyclone landfall (Vitart et al. 2003).

Extensive research has been performed on the influence of SWIO variability on southern African rainfall (e.g. Jury and Nkosi 2000, Reason 2002, Washington and Preston 2006). This paper will describe the synoptic circulation anomalies associated with the most recent surge in direct influence of tropical cyclonic systems from the SWIO on southern Africa, within the context of the maximum in the bi-decadal Dyer-Tyson cycle during the late 1990s. The bidecadal cycle in the frequency of occurrence of landfalling tropical systems over southern Africa is also placed within the context of circulation anomalies of the $\mathrm{SH}$, specifically the SAM.

\section{Data and Methodology}

NCEP Reanalysis I data (Kalnay et al. 1996) at a $2.5^{\circ}$ spatial and daily temporal resolution for the years 1979 to 2011 are used in the analysis of large-scale synoptic fields over the Area of Interest (AOI - Fig. 1). The geopotential heights at 17 standard pressure levels are considered. 


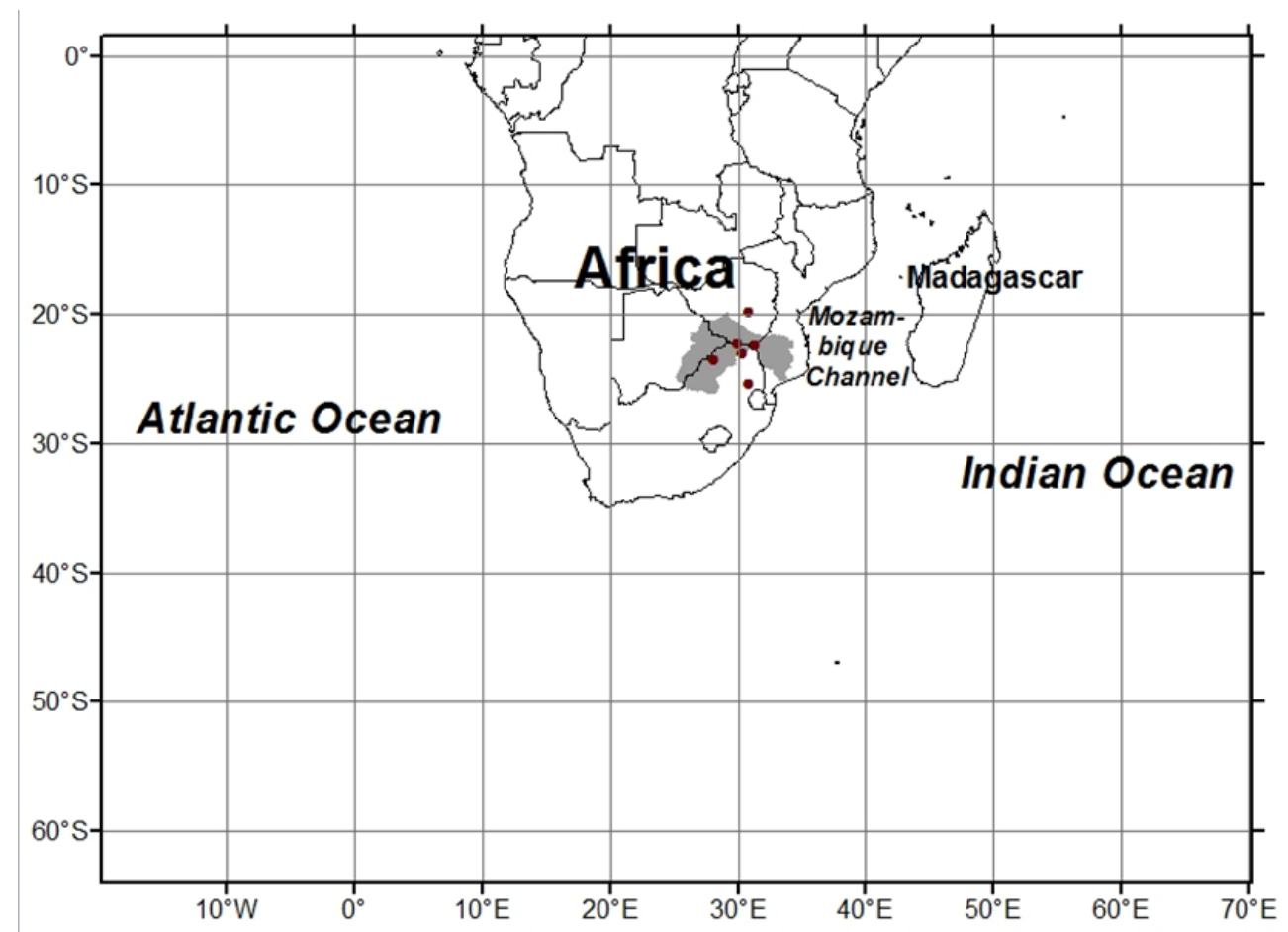

Fig. 1 Area of interest (the Limpopo River Basin is indicated as well as 8 rainfall stations used later in the analysis).

Data are firstly considered for the period 1979 to 2011 for the analysis of regional anomalies, due to the superior quality of the data since the inclusion of more surface observations over the southern high latitudes since the early 1970s (Hines et al. 2000) and inclusion of satellite data from 1979 onwards (Kanamitsu et al. 1997, Sturaro 2003, Tennant 2004). Since landfalling systems that cause high rainfall totals over the Limpopo River Basin only occur during the three-month season of January through March (JFM - Malherbe et al. 2012), our study will subsequently focus on this part of the austral summer season. During this period, tropical systems in general control the summer circulation to a large extent (Preston-Whyte and Tyson 2000). Rainfall data for the period, representing parts of the Limpopo River Basin, are considered for eight rainfall stations with locations indicated in Fig. 1.

The study firstly employs a Self-Organizing Map (SOM) analysis (Kohonen 2001) towards understanding synoptic circulation associations with landfall events of tropical systems resulting in rainfall over the Limpopo River Basin. The analysis using SOMPAK 3 (Kohonen et al. 1996) is performed to classify regional synoptic patterns of geopotential heights, for each of the standard atmospheric levels from $1000 \mathrm{hPa}$ to $30 \mathrm{hPa}$ separately. The synoptic data considered are for each day during JFM within the 1979-2011 period. The analysis is performed on the standardized values to compensate for latitudinal difference in magnitude of variation. By studying the synoptic-scale patterns associated with the nodes of the SOM analysis, and taking the error when associating synoptic conditions with the SOM nodes into account, it was decided to use a 25-node 5X5 SOM. The nodes resulting from the SOM analysis are evaluated in terms of the percentage of days with landfalling systems mentioned above relative to the total number of days represented by that node. The yearly JFM time series of the nodes are considered towards identifying the presence of synoptic-scale variability supporting the prominence of rainfall caused by tropical systems from the SWIO during a sub-period. Any grouping of the resulting SOM nodes is done by classifying the existing 25 nodes resulting from SOM analysis again using the SOM analysis software. 
A change-point analysis (Taylor 2000, Cram et al. 2003) is performed on the normalized yearly rainfall contributed by tropical systems from the SWIO at the six stations (Fig. 1). Identification of these systems and associated rainfall are detailed in Malherbe et al. (2012). The results of the change-point analysis, supported by the SOM node time series, are used to identify the specific sub-period during which tropical systems from the SWIO contributed significantly more rain than the climatological average. Various tropospheric variables are then considered and contrasted to the rest of the 1979-2011 period. These variables, important to the movement of tropical systems and rainfall over southern Africa, are: low level and upper air geopotential height, 700-500 hPa steering flow, 850-250 hPa wind shear, low level relative vorticity and relative humidity at $600 \mathrm{hPa}$. Statistical significance is determined by comparison of results to a thousand randomized time series generated through Monte Carlo simulations (Wilks 2011), from the observed annual JFM averages for the same period.

Certain large-scale anomalous circulation features characterizing the wet sub-period are subsequently considered together with the SAM, to identify possible global characteristics of the bi-decadal variation observed in rainfall data. This is done for the entire 1948-2011 period, spanning the period of data availability of NCEP Reanalysis I. Here, the SAM is calculated by taking the difference between the normalized $850 \mathrm{hPa}$ height anomalies per grid point between $40^{\circ} \mathrm{S}$ and $65^{\circ} \mathrm{S}$. These are the same latitudes used by Gong and Wang (1999) in their calculation of the SAM from Sea Level Pressure data. Ho et al. (2012) found the stationbased index by Marshall (2003) to be superior to reanalysis-based definitions. For the period of station data availability (1958-2012) for that index, the Pearson correlation between the SAM calculated for JFM in the present study with the station-based index is 0.85 .

The relationship between Austral summer rainfall over southern Africa and ENSO is well known (Ropelewski and Halpert 1987, Nicholson and Kim 1997, Reason et al. 2000, Reason et al. 2005). While no significant correlation exists between the SAM and ENSO during JFM or any of the individual months December through April (Pohl et al. 2010), caution is advised when attributing an apparent correlation between summer rainfall during November-toFebruary to the SAM while it may in fact be a result of ENSO variability. The focus of the current study is bi-decadal variability, focusing on circulation patterns in the JFM season. While associations between ENSO and rainfall is expected on inter annual basis, the interest of the current research rather lies in the multi-year variability, which may also be noticeable in the regional anomalies and magnitude of impacts associated with ENSO, and which may also be detected in rainfall at a multi-year timescale. An example of a similar situation in the Northern Hemisphere is the modulating effect the North Pacific Oscillation has on the impacts of ENSO over North America (Gershunov and Barnett 1998). A Fourier analysis is therefore performed for low-frequency (5-year and longer) variability of the JFM SAM, JFM rainfall and the JFM SOI in the current study.

The study ends with an overview of circulation anomalies over the southern African region during decadal wet and dry epochs during the entire 1948-2011 period. Trends in the average JFM geopotential height as well as $\mathrm{U}$ and $\mathrm{V}$ vectors during this period are calculated for each gridpoint using the method of pairwise slopes (Lanzante 1996). These trend values are subsequently used to detrend the 1948 to 2011 JFM geopotential, U and V vector values prior to analysis. The detrended data are used to calculate the association between the (detrended) SAM and circulation anomalies in the southern African region and to calculate anomalies for each complete wet and dry epoch since 1948. 


\section{Results and Discussion}

\section{Synoptic circulation associations with landfalling tropical systems}

The total number of landfalling tropical systems responsible for rain at the eastern stations over the area of interest (dark circles in Fig. 1) during 1979-2011 is 18 (Malherbe et al., 2012). The associated synoptic sequences account for 110 days out of a total of 3240 days (90 days per JFM over 33 years). Based on the percentage representation of these 110 days within each of the 25 nodes, landfall of tropical cyclonic systems causing rainfall over the Limpopo River Basin is found to be associated with very specific anomaly patterns from the $1000 \mathrm{hPa}$ to $100 \mathrm{hPa}$ levels. Above the $100 \mathrm{hPa}$ level, trends in the time series during the study period dominate the results for these levels and are excluded from further analysis.

The results of the SOM analysis for the $850 \mathrm{hPa}$ and $250 \mathrm{hPa}$ levels are shown in Fig. 2a and $2 \mathrm{~b}$. These figures provide a summary of the associations found through the troposphere, focusing on favourability of synoptic conditions for landfall and also rainfall contributed by tropical systems over the Limpopo River Basin. The Sammon map is shown for both these levels also with an indication of the extent to which each of the 25 SOM nodes favours the synoptic sequence (landfall, propagation into the subcontinent): darker (lighter) shades indicate more (less) favourable synoptic conditions. The distances between the nodes in the Sammon map is an indication of how much the various synoptic states associated with each node differ from the synoptic states associated with surrounding nodes in terms of spatial distribution and size of anomalies. 

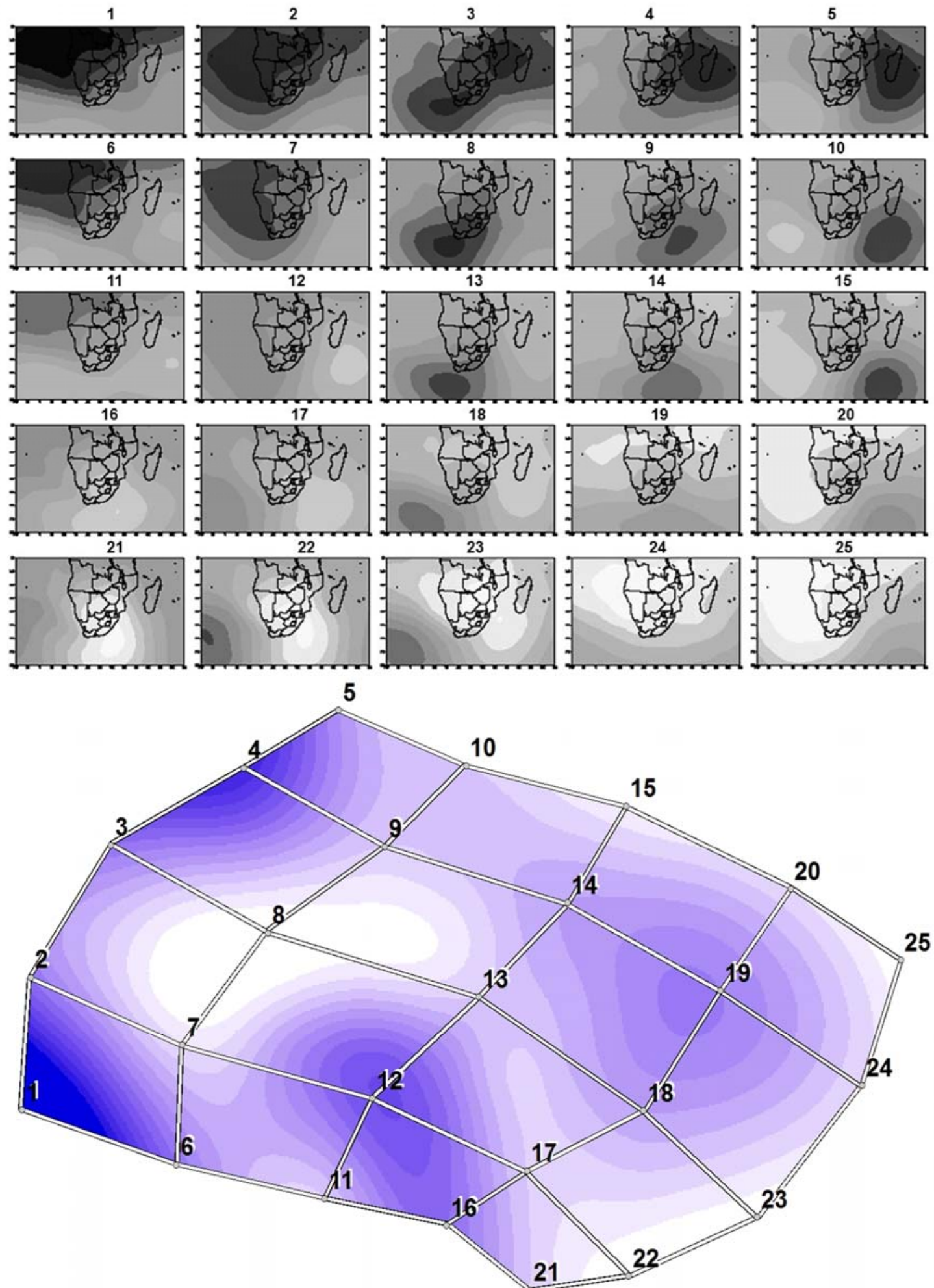

Fig. 2a SOM based on the standardized values with lighter (darker) shades showing positive (negative) deviations for the $850 \mathrm{hPa}$ level (top), and Sammon map (bottom) showing the concentration of days associated with landfall and movement of tropical systems from the SWIO into the Limpopo River Basin for each SOM node. In the Sammon map, darker shades represent a higher concentration of days with landfall events. Numbers on the Sammon map correspond to the numbers of the nodes in the SOM. The 5 most favourable SOM nodes at this level are highlighted. 


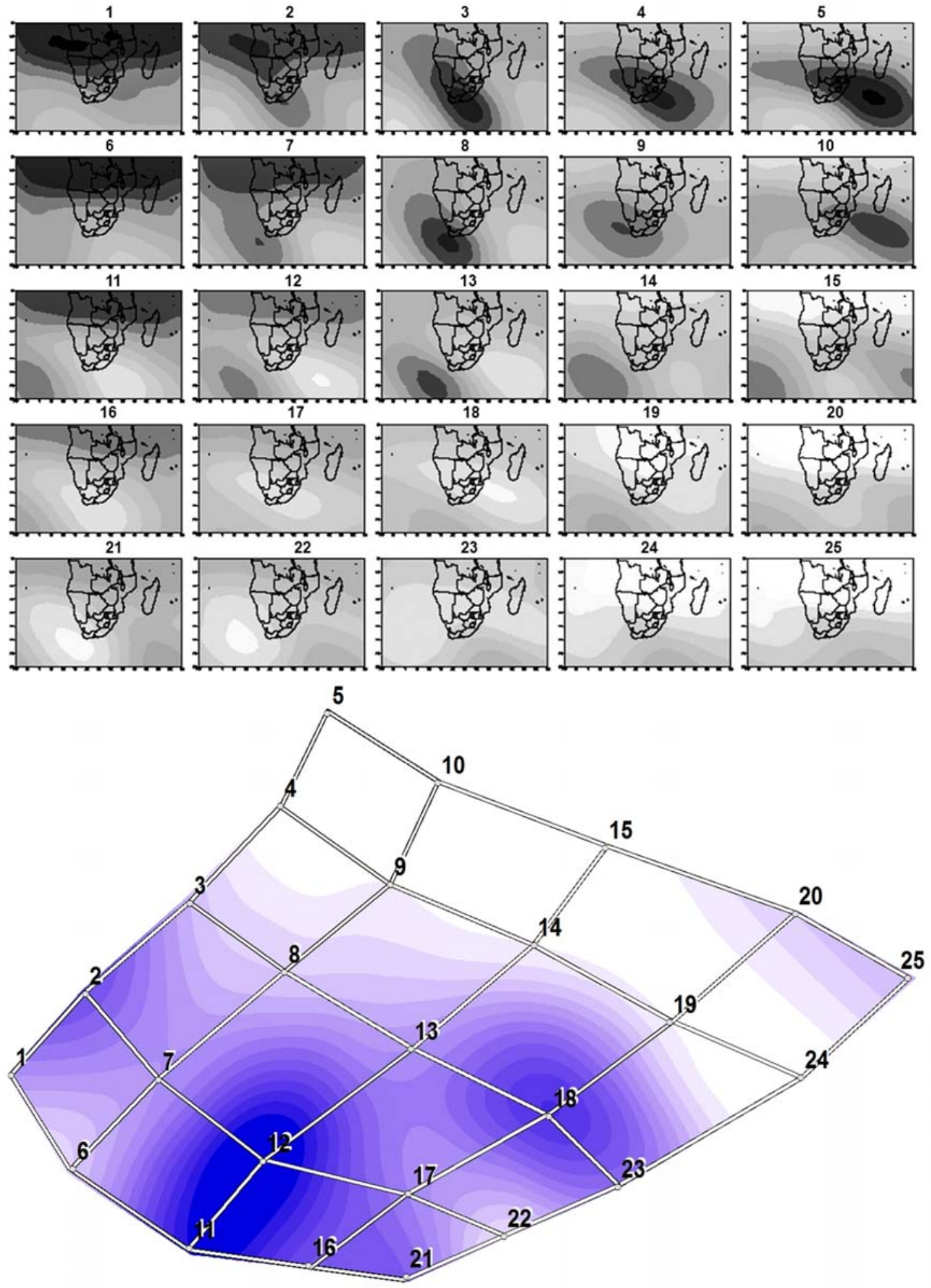

Fig. 2b As for Fig. 2a, but for $250 \mathrm{hPa}$.

Results are more coherent with increasing height from $850 \mathrm{hPa}$ to $100 \mathrm{hPa}$ (not shown), with a more distributed occurrence of favourable versus unfavourable nodes at the lower levels. 
From Fig. 2, the following main circulation categories, and their relation to landfall, may be indicated:

The patterns at the $850 \mathrm{hPa}$ to $100 \mathrm{hPa}$ levels that are associated with landfall events are:

- Negative deviations in height to the north of southern Africa associated with weak or strong positive deviations to the south of the country;

- Positive deviations towards the southeast of the subcontinent and negative deviations towards the southwest of the subcontinent.

The patterns at the $850 \mathrm{hPa}$ to $100 \mathrm{hPa}$ levels that are not associated with landfall events are:

- Positive deviations in height to the north of southern Africa associated with weak or strong negative deviations to the south of the country;

- Negative deviations towards the southeast of southern Africa.

These SOM results indicate an association in landfall events with anticyclonic anomalies towards the south and southeast of southern Africa and cyclonic anomalies over the subcontinent. These anomalies are also associated with above-normal rainfall over much of southern Africa (Tyson 1981).

\section{Decadal variability of synoptic nodes}

Based on the 4 synoptic circulation patterns relevant to landfall of tropical systems from the SWIO and movement into the Limpopo River Basin, as identified above, the 25 SOM nodes at each standard level have been reclassified into 4 groups:

- Negative deviations in height to the north of southern Africa associated with weak or strong positive deviations to the south of the country (subsequently referred to as Pattern A+);

- Positive deviations in height to the north of southern Africa associated with weak or strong negative deviations to the south of the country (Pattern A-);

- Positive deviations towards the southeast of the subcontinent and negative deviations towards the southwest of the subcontinent (Pattern $B+$ );

- Negative deviations towards the southeast of southern Africa (Pattern B-).

Pattern $\mathrm{A}+(-)$ is an indication of positive (negative) anomalies over a wide region to the south of southern Africa, stretching from $20^{\circ} \mathrm{W}$ to $60^{\circ} \mathrm{E}$. Pattern $\mathrm{B}+(-)$ is an indication of positive (negative) anomalies specifically towards the southeast and east of southern Africa, between $30^{\circ} \mathrm{E}$ and $60^{\circ} \mathrm{E}$. Fig. 3 shows the percentage of days with which tropical systems making landfall and tracking into the Limpopo River Basin are associated within each of the four groups (Pattern $\mathrm{A}+/$ - and Pattern $\mathrm{B}+/-$ ) with height. 


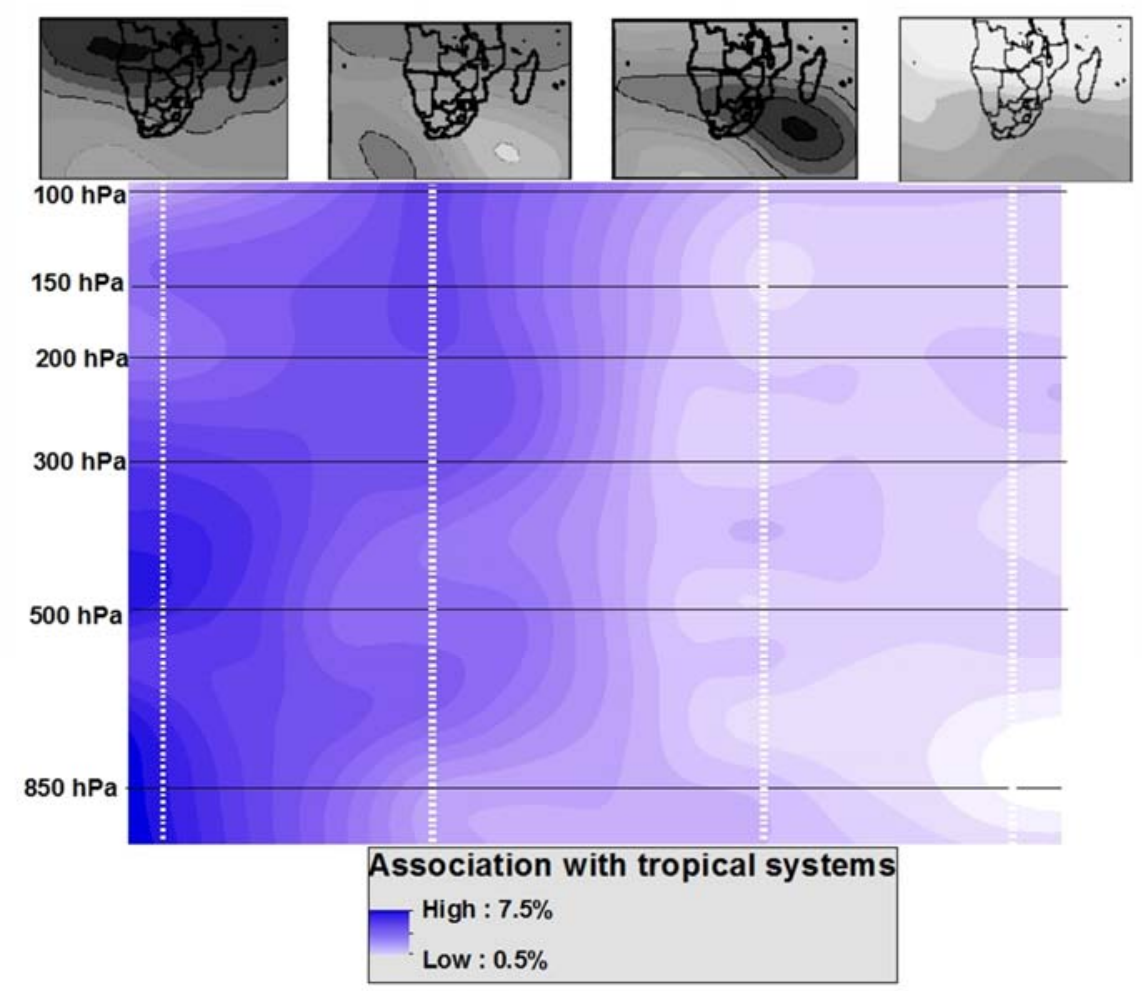

Fig. 3 Variation in concentration within each of the four SOM groups (indicated at the top) of landfallevent days per pressure level. The pressure levels are represented on the vertical from bottom (1000 hPa) to top (100 hPa).

The frequency of occurrence of landfall days is indicated in Fig. 3 with higher (lower) concentration shown in darker (lighter) shades. It provides insight into the vertical structure of the geopotential height anomalies occurring when tropical systems make landfall and move into the Limpopo River Basin. Throughout the troposphere, the positive anomalies in pressure for the entire region to the south of the subcontinent $($ Pattern $\mathrm{A}+$ ) or to the southeast only $($ Pattern $\mathrm{B}+$ ) are associated with rainfall contributed by tropical systems from the SWIO over the Limpopo River Basin as opposed to the other two patterns. At the lower levels (from $1000 \mathrm{hPa}$ to about $400 \mathrm{hPa}$ ), Pattern A is most strongly associated with landfall (largest contrast in concentration found between the far left and far right in Fig. 3). From $300 \mathrm{hPa}$ to $100 \mathrm{hPa}$, the strongest contrast is associated with Pattern B (largest contrast between the middle left and middle right). To summarize, this indicates that while anomalously high pressure towards the southern parts of the region of interest favours landfall and precipitation contribution by tropical systems, positive anomalies towards the southeast specifically becomes more important with increasing height, indicating the presence of a deep anticyclonic anomaly throughout the troposphere in that region. Tropical systems moving into the Limpopo River Basin only occurred on roughly $4 \%$ of the total number of days during JFM over the 33-year period, resulting in the seemingly low percentages association with the 4 groups in Fig. 3.

Change-point analysis based on the average normalized rainfall at the stations over the Limpopo River Basin (marked stations in Fig. 1 - Malherbe et al. 2012) contributed by tropical systems from the SWIO indicates that the period 1995 to 2002 can be considered to be anomalous from the rest of the time series spanning the period 1979 to 2011, with a 
significance exceeding the $90 \%$ level of confidence. The rest of the analysis will focus on this period, based on the altered contribution to rainfall by tropical systems.

As the association of the deep anticyclonic anomaly towards the southeast of southern Africa with tropical cyclone landfall and precipitation over the Limpopo River Basin has now been identified, the variation of this anomaly (occurrence of Pattern B) from the $250 \mathrm{hPa}$ up to $100 \mathrm{hPa}$ determined through SOM analysis, is considered. This is done towards understanding the higher concentration of landfall and a larger contribution to rainfall over the eastern parts of the subcontinent during the 1995-2002 period. Fig. 4 shows the yearly total rainfall contributed by tropical systems from the SWIO, averaged over the 4 eastern rainfall-recording stations (dark circles in Fig. 1). Also shown is the time series of the balance of positive and negative occurrences (number of days with positive minus number of days with negative) of Pattern B as averaged over the entire 250-100 hPa depth. El Niño and La Niña events (NOAA Web Page 2012) are also indicated.

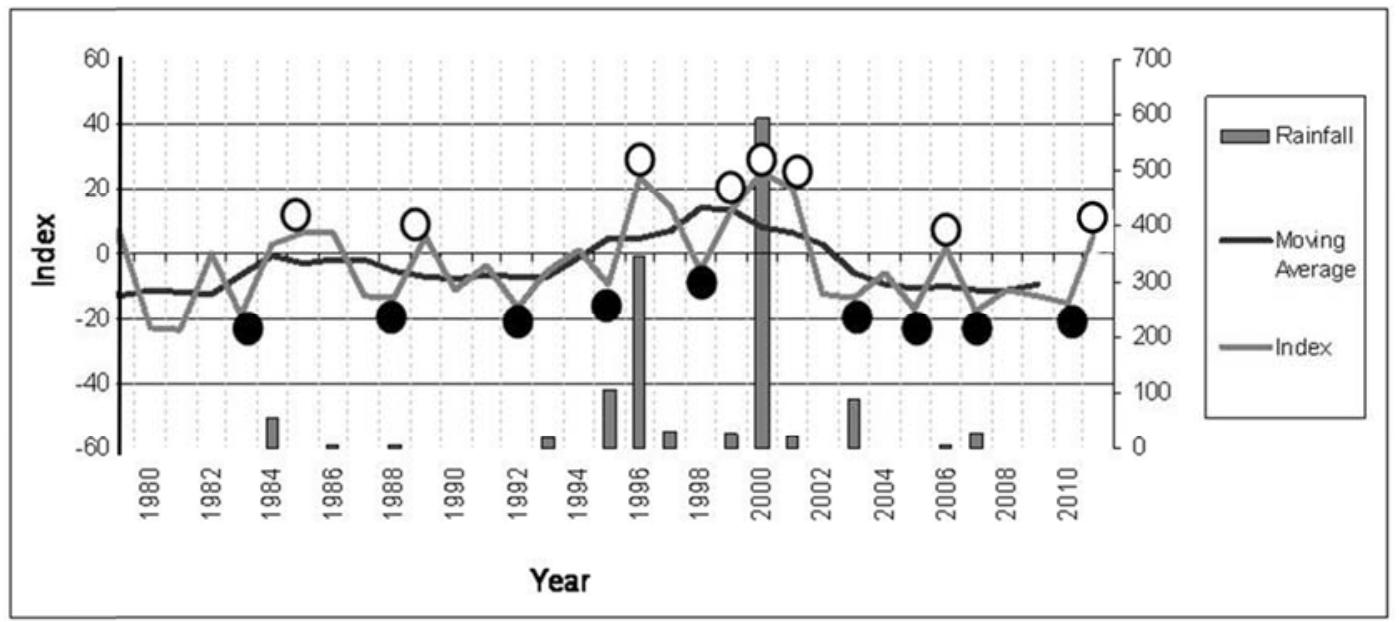

Fig. 4 Time series of the difference between the number of occurrences of Pattern B Positive and Pattern B Negative per JFM season (grey line, primary y-axis), 5-year moving average (black line) and annual rainfall (bars, secondary y-axis, units: $\mathbf{m m}$ ) associated with tropical systems from the SWIO. EI Niño and La Niña event years are indicated by solid and open circles, respectively.

The occurrence of anticyclonic anomalies towards the east of the subcontinent (Pattern $\mathrm{B}+$ ) reaches a maximum during the 1995-2002 period. The variation in time of this pattern (Fig. 4) over time is influenced by the occurrence of ENSO, but further also displays a modulation causing it to be more prevalent during La Nina / El Nino events from 1993 to 2002 compared to the rest of the time series. This is not the case for Pattern A (not shown). The variation since 1979 of Pattern B, as an average over all standard pressure levels up to $100 \mathrm{hPa}$, is also reflected at the individual levels (not shown). Variations in the geopotential pattern are therefore visible throughout the troposphere up to $100 \mathrm{hPa}$ (not shown), with a maximum from 1993 to 2002. This maximum is consistent with the change-point analysis which indicates that much of this period was characterized by enhanced contribution of rainfall by tropical systems from the SWIO. The average low level $(850 \mathrm{hPa})$ and upper air (250 hPa) geopotential height anomalies for the period 1995-2002 relative to the average for the rest of the 1979-2011 period (Fig. 5) is a further reflection on the anomalous occurrence of certain nodes as indicated by the SOM time series in Fig. 4. 


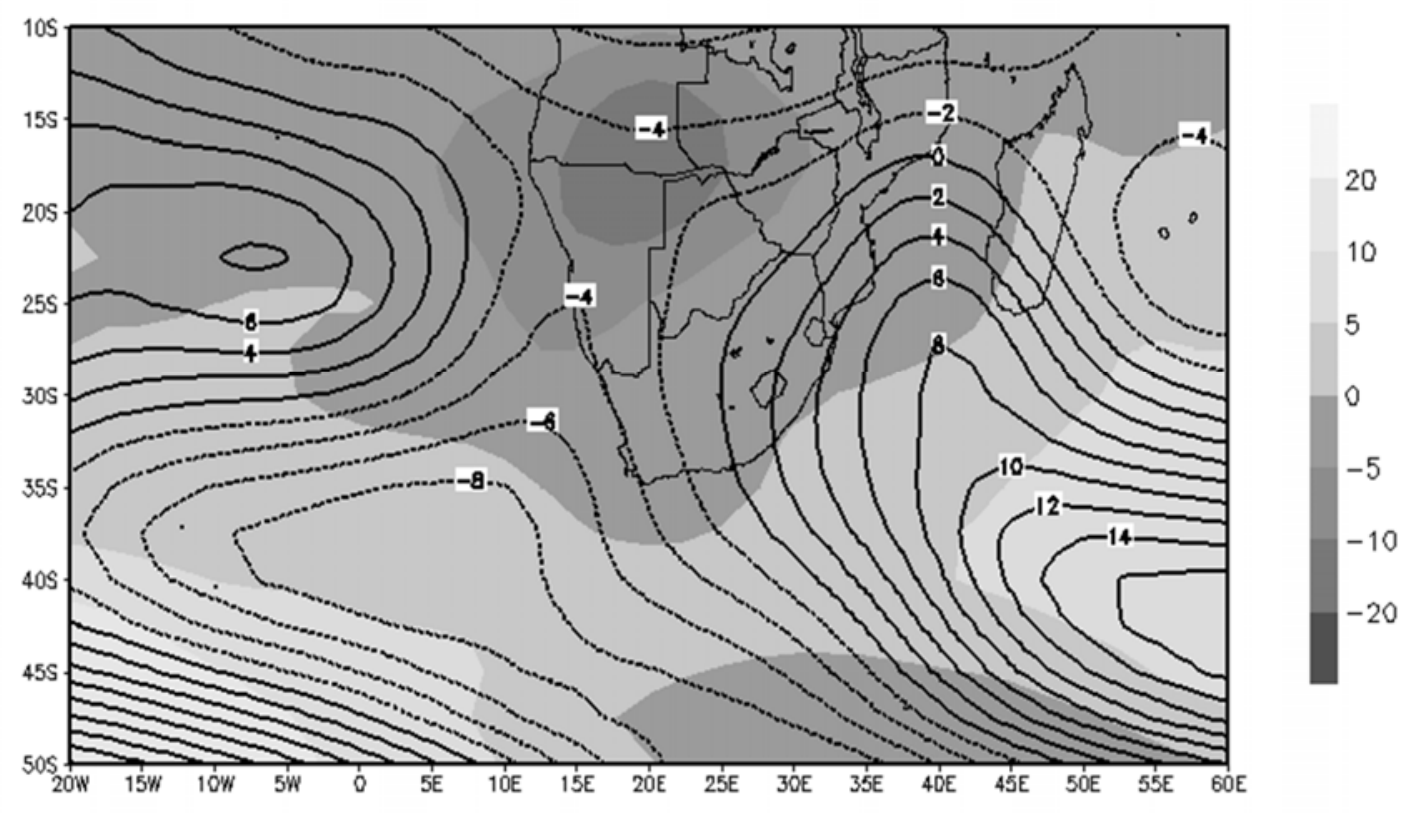

Fig. 5850 hPa (shaded) and 250 hPa (contours) height anomalies (units: m) for the 1995-2002 period.

The $850 \mathrm{hPa}$ height anomalies reflect the same patterns as those associated with the earlier multi-year wet periods (Tyson 1981, Reason and Rouault 2002) and ENSO cold events (Reason et al. 2000). Negative anomalies over the subcontinent and positive anomalies towards the south dominate. At $250 \mathrm{hPa}$ the most outstanding feature is the anticyclonic anomaly to the east of southern Africa as well as negative anomalies towards the southwest of the subcontinent, or Pattern B+ from the SOM analysis, already shown to be more frequent during this period (Fig. 4). Positive anomalies in geopotential height towards the eastern parts of the AOI throughout the troposphere occur during years of anomalously easterly flow, associated earlier with positive rainfall anomalies over southern Africa (Jury and Nkosi 2000). Stronger west winds are further located towards the south of this anomaly. Considering now the vertical profile of zonal wind anomalies, for the same sub-period, Fig. 6 shows the zonal wind anomalies to the east of southern Africa at $40^{\circ} \mathrm{E}$, near the east coast of Africa. 


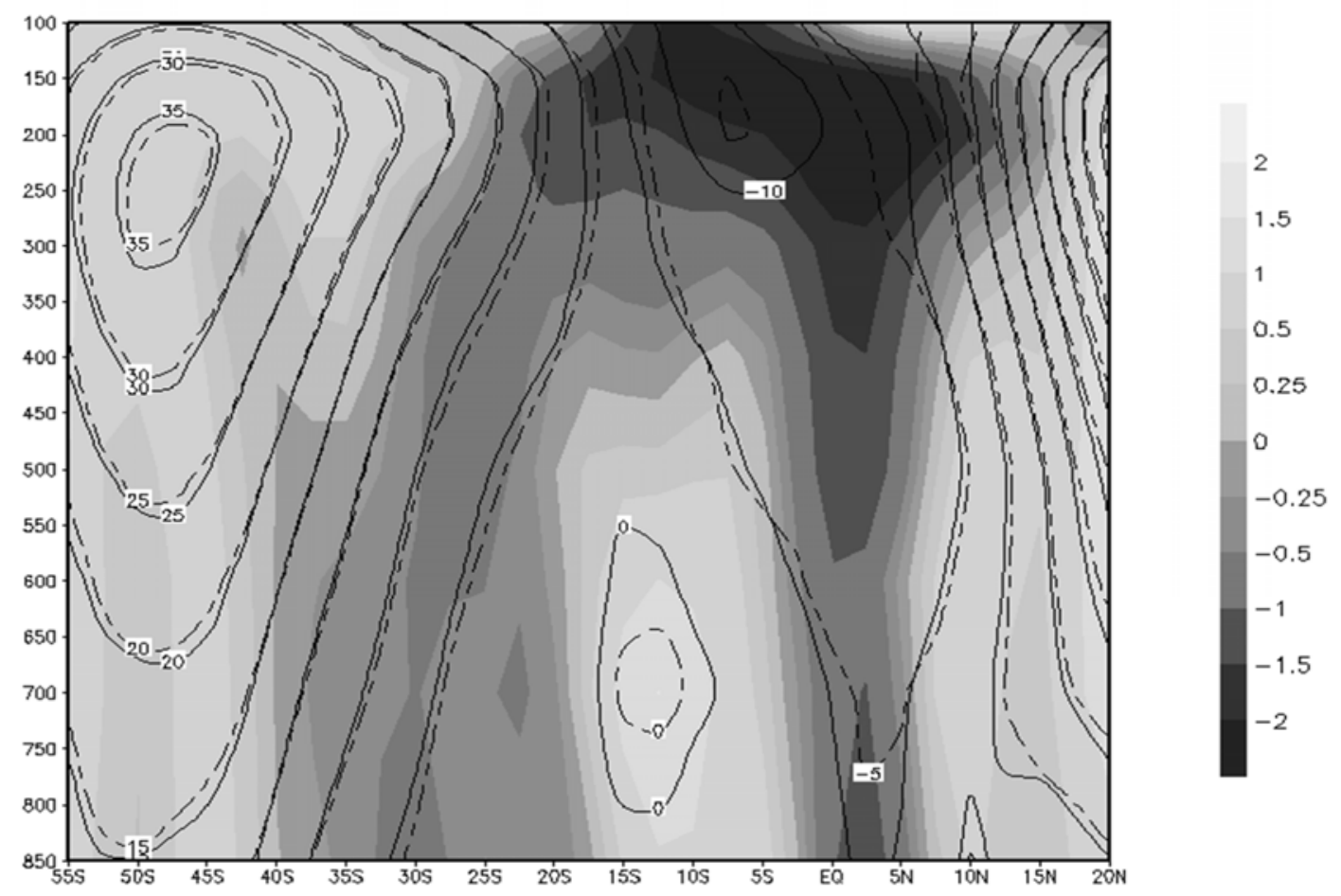

Fig. 6 Average zonal wind along $40^{\circ} \mathrm{E}$ during the 1995-2002 period (solid contours, units: $\mathrm{ms}^{-1}$ ), compared to the rest of the 1979-2011 period (dashed contours) and the difference (shaded).

The zonal wind anomalies during the 1995-2002 period, calculated with respect to the remaining years of the 1979-2011 period, display the following characteristics:

- Intensification of subtropical easterlies in the lower to middle troposphere and intensification of westerlies to the south;

- Southward contraction or weakening of the Jet stream from north of $35^{\circ} \mathrm{S}$;

- Stronger upper air Jet stream towards $50^{\circ} \mathrm{S}$;

- Stronger Equatorial upper easterly Jet stream;

- Stronger Equatorial westerlies in the lower to middle troposphere.

These zonal anomalies show a broadening in the Hadley cell and a Walker circulation anomaly during this period. This feature in the zonal flow is visible over a wide area surrounding southern Africa. The anomalously easterly flow over the subtropics $\left(40^{\circ} \mathrm{S}\right.$ to $15^{\circ} \mathrm{S}$ ) and westerlies further south ( $55^{\circ} \mathrm{S}$ to $45^{\circ} \mathrm{S}$ ) are visible throughout the column below $100 \mathrm{hPa}$. The boundary between the relatively westerly flow towards the south and the relatively easterly flow towards the north around $40-30^{\circ} \mathrm{S}$ throughout the column represents the center of the deep anticyclonic anomaly. In the middle troposphere it is significant above the 95\% confidence level for the 1995-2002 period and above 99\% confidence level for the 1993-2000 period (Fig. 7). 


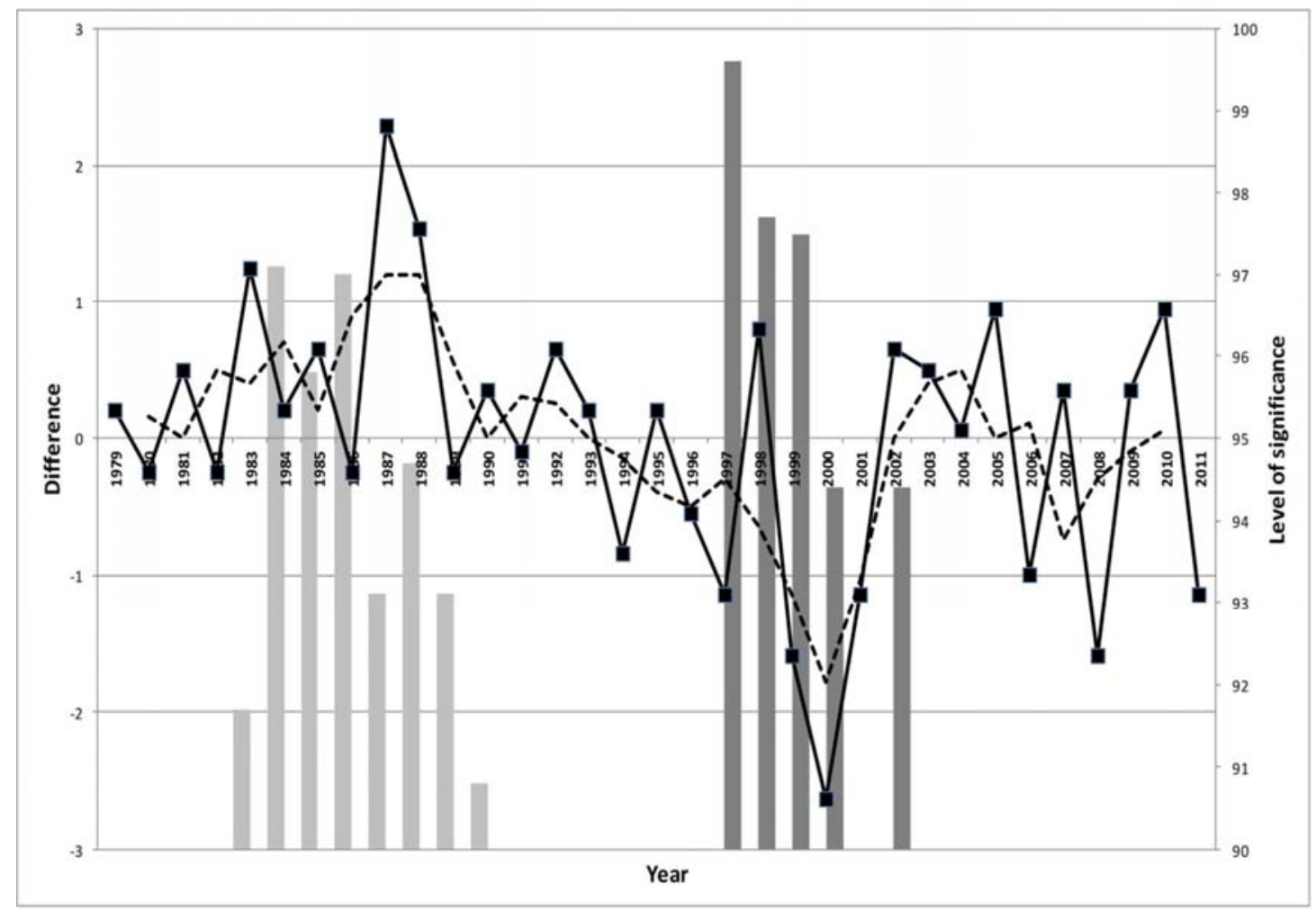

Fig. 7 Time series of normalized difference in zonal wind $\left(40-15^{\circ} \mathrm{S}\right.$ minus $\left.55-45^{\circ} \mathrm{S}\right)$ at $600 \mathrm{hPa}$ (black solid line), 3-year moving average (broken line) and level of significance (secondary y-axis) exceeding $90 \%$ for moving 8-year above-average value (light grey bars) and 8-year below-average value (dark grey bars).

Other features visible in Fig. 7 such as the weakening and southward displacement of the upper air subtropical Jet stream with a strengthening towards $50^{\circ} \mathrm{S}$ as well as the Walker cell anomaly (Fig. 6) are also associated with wetter conditions over southern Africa (Tyson 1981, Tyson et al. 1997). These however don’t attain a level of significance exceeding 95\% during the sub-period. It is concluded that especially the broadening of the Hadley circulation, associated with the deep anticyclonic anomaly to the east of the subcontinent, defines the contrasting tropospheric conditions within the region during the 1995-2002 period.

\section{Implications of variable synoptic conditions for tropical systems}

Steering flow, low-level convergence, mid-tropospheric relative humidity, low level relative vorticity and vertical wind shear are all factors considered important to tropical cyclone tracks and intensity. These will now be considered for the 1995-2002 sub-period relative to the rest of the 1979-2011 period. The $700 \mathrm{hPa}$ to $500 \mathrm{hPa}$ levels have been singled out over the SWIO as important steering flow level for tropical cyclones SWIO (Jury and Pathack 1991). Fig. 8 shows the anomalous steering flow during the sub-period. 


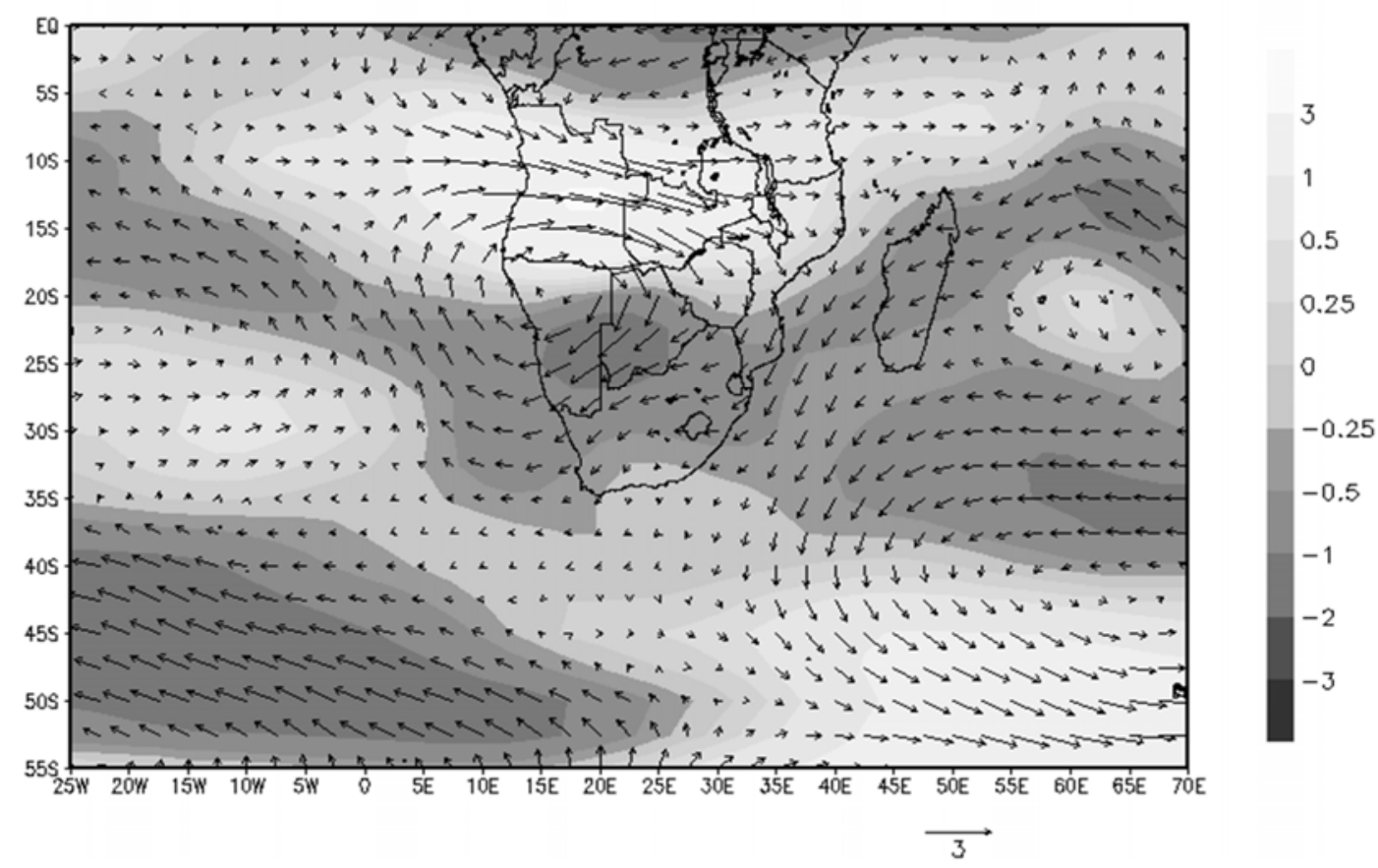

Fig. 8 Difference wind vectors (scale shown, units: $\mathrm{ms}^{-1}$ ) of the 700-500 hPa flow for the period 1995-2002 (difference in zonal component shaded, units: $\mathrm{ms}^{-1}$ ) compared to the rest of the 1979-2011 period.

Wind vectors over much of the mid-latitudes and subtropics, between $45^{\circ} \mathrm{S}$ and $15^{\circ} \mathrm{S}$, are anomalously east (Fig. 8). The strengthened easterlies over the subtropics at these levels indicate an enhanced westward steering flow for tropical systems during the 1995-2002 subperiod into the subcontinent. The mid-level cyclonic anomaly over northern Namibia / southern Angola in Fig. 8 represents the deepening of the Angola Low, which is located on the northern flank of the anomalously easterly flow. The strengthened easterly flow is also reflected from the surface to the upper troposphere (not shown). On the northern flanks of enhanced easterlies there is a large elongated area of increased convergence at $850 \mathrm{hPa}$ and increase in relative humidity (RH) at $600 \mathrm{hPa}$ between $10^{\circ} \mathrm{S}$ and $20^{\circ} \mathrm{S}$ (Fig. 9), showing a southward displacement of the Inter-Tropical Convergence Zone (ITCZ). This is visible over both the subcontinent and SWIO, but most strongly in the area of intensification of the Angola low. 


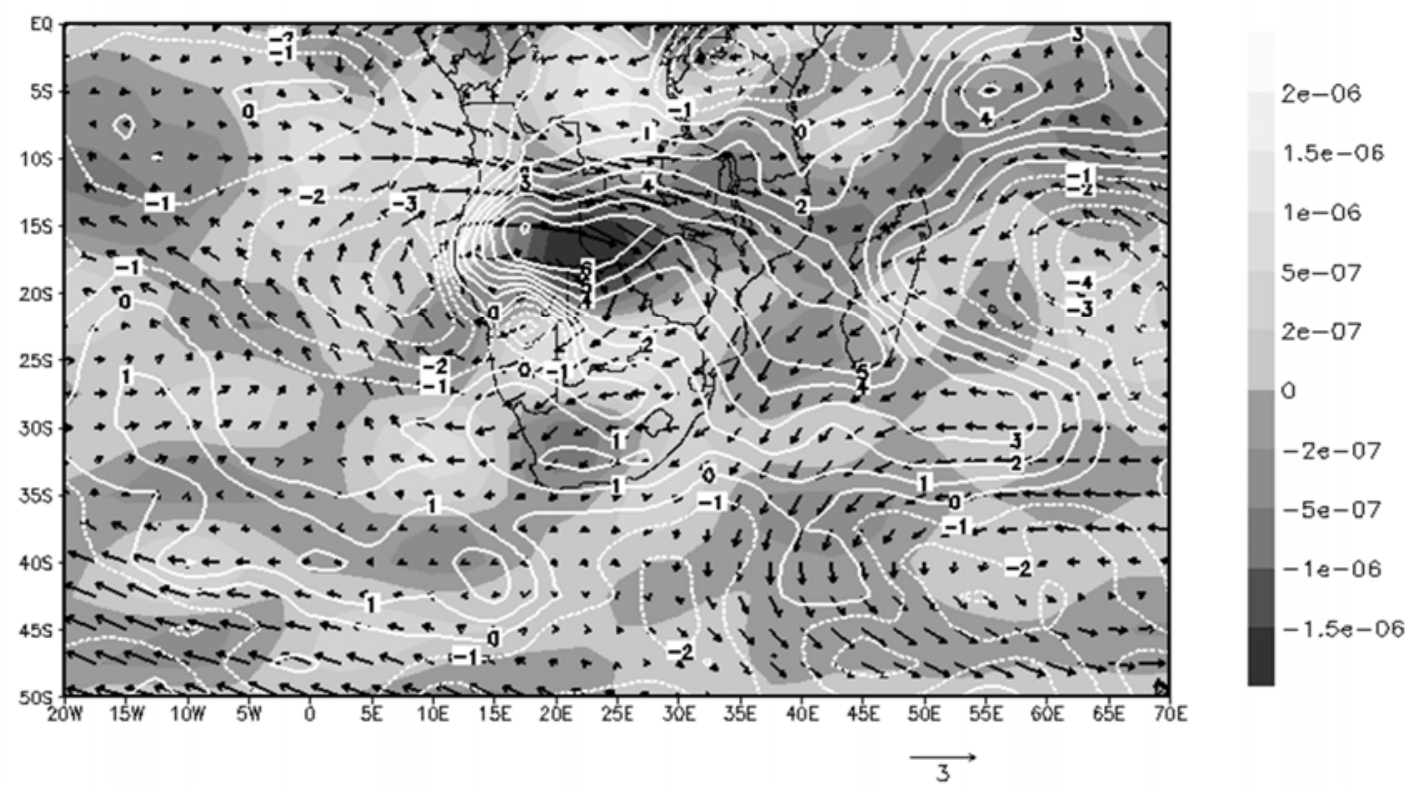

Fig. 9 Difference in $850 \mathrm{hPa}$ convergence (shaded, units: $\mathrm{s}^{-1}$ ) and difference in relative humidity at $600 \mathrm{hPa}$ (white contours, units: \%). $850 \mathrm{hPa}$ wind vector anomalies for the period 1995-2002 relative to the remaining years in the period 1979-2011 are also indicated (scale shown).

An increase in RH, as seen from the $600 \mathrm{hPa}$ anomaly over much of southern Africa including the Limpopo River Basin (Fig. 9), is associated with the enhanced easterly flow in the lower to mid-troposphere into southern Africa together with the southward displacement of lowerlevel convergence. The anomalous circulation pattern therefore enhances zonal transport of moisture and a southward displacement of the ITCZ over Africa. The increase in RH over Africa and towards Madagascar also indicates increased thermal potential for the development and sustenance of tropical systems over these areas.

The boundary between the increased easterly flow over a large part of the subtropics and anomalously westerly flow towards the north of $15^{\circ} \mathrm{S}$ (Fig. 8) identifies an area of enhanced negative relative vorticity (Fig. 10). 


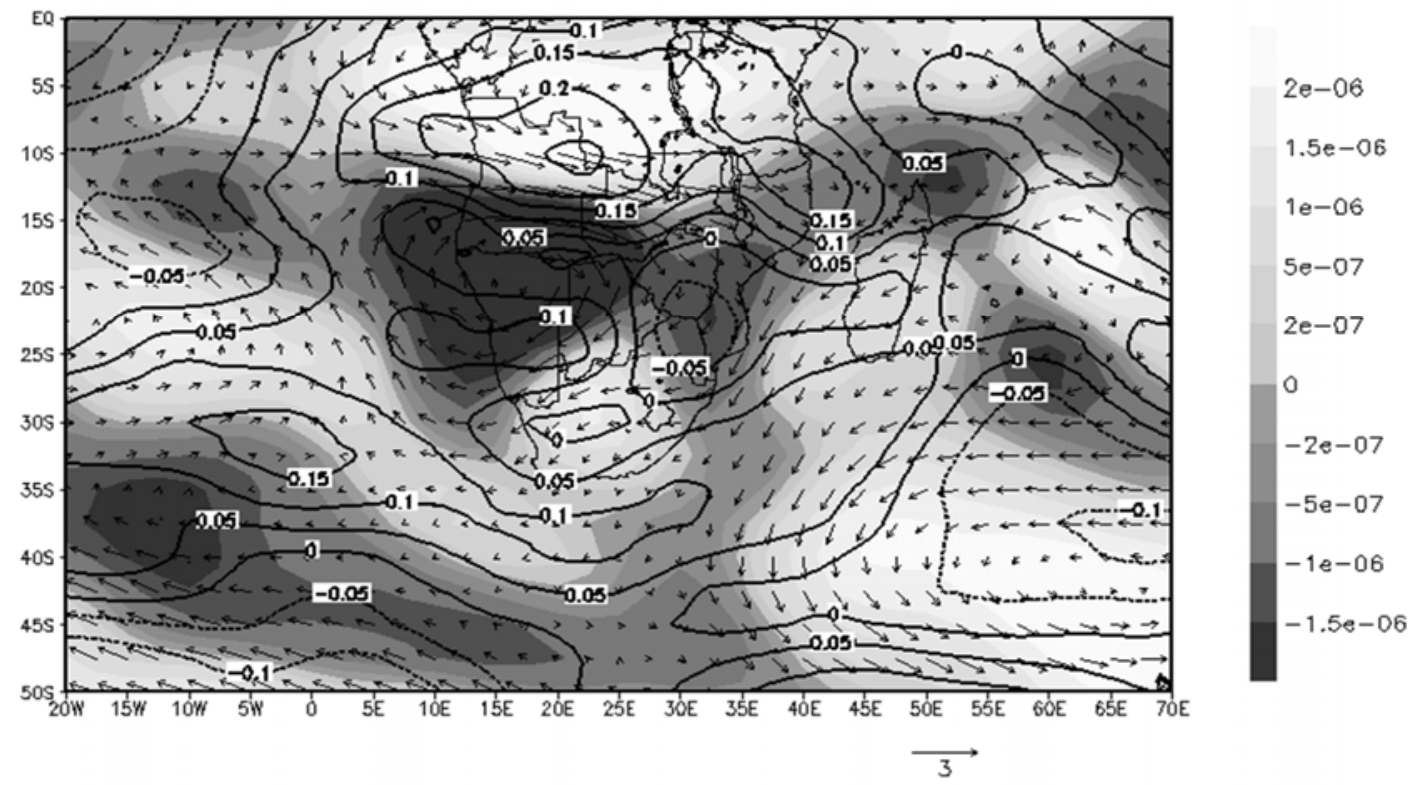

Fig. 10 Difference in $850 \mathrm{hPa}$ relative vorticity (shaded, units: $\mathrm{s}^{-1}$ ), wind shear between $850 \mathrm{hPa}$ and $200 \mathrm{hPa}$ (black contours, units: $\mathrm{ms}^{-1} / \mathrm{km}$ ) and wind vectors (scale shown) for the period 1995-2002 relative to the remaining years in the period 1979-2011.

Negative vorticity is enhanced in the region of the Angola Low, stretching zonally eastward to northern Madagascar and further east into the SWIO along the northern edge of enhanced easterlies. This region (around $15^{\circ} \mathrm{S}$ ) over the SWIO is important for cyclogenesis and anomalous negative vorticity represents an increase in dynamical potential for development of tropical cyclones, a situation associated with ENSO cold events (Vitart et al. 1999). Furthermore, wind shear between $850 \mathrm{hPa}$ and $200 \mathrm{hPa}$ increases over southern Africa towards the north of $15^{\circ} \mathrm{S}$ and towards the south of $30^{\circ} \mathrm{S}$, with smaller increases over much of the $30-15^{\circ} \mathrm{S}$ region, and even a decrease over much of the Limpopo River Basin and into the SWIO crossing southern Madagascar. This relative decrease in wind shear and enhanced negative vorticity over much of subtropical southern Africa represent dynamical features conducive to the development of tropical systems over the SWIO and also into the Limpopo River Basin. The intensification of the Angola Low together with increased moisture and low level convergence over much of southern Africa further represent more favourable conditions for rainfall over the Limpopo River Basin and in fact much of southern Africa (PrestonWhyte and Tyson 2000).

The increase in positive vorticity towards the southeast of the subcontinent where the deep anticyclonic anomaly occurs has important implications for moisture transport and rainfall over the southern African region. It is over this part of the SWIO where negative vorticity advection due to transient eddies in the westerlies, leading to the development of the midlatitude Rossby wave, has been indicated to enhance dry conditions over the subcontinent during ENSO warm events (Cook 2000). The anticyclonic anomaly over this area therefore represents a modulation in the regional atmosphere important to ENSO teleconnections over southern Africa. 


\section{Decadal variation within context of circulation of the hemisphere}

Over the Southern Hemisphere, the sub-period 1995-2002 is associated with positive geopotential height anomalies over much of the mid-latitudes and negative anomalies over Antarctica, throughout much of the troposphere. While evident throughout much of the troposphere, this is demonstrated for the $500 \mathrm{hPa}$ level in Fig. 11.

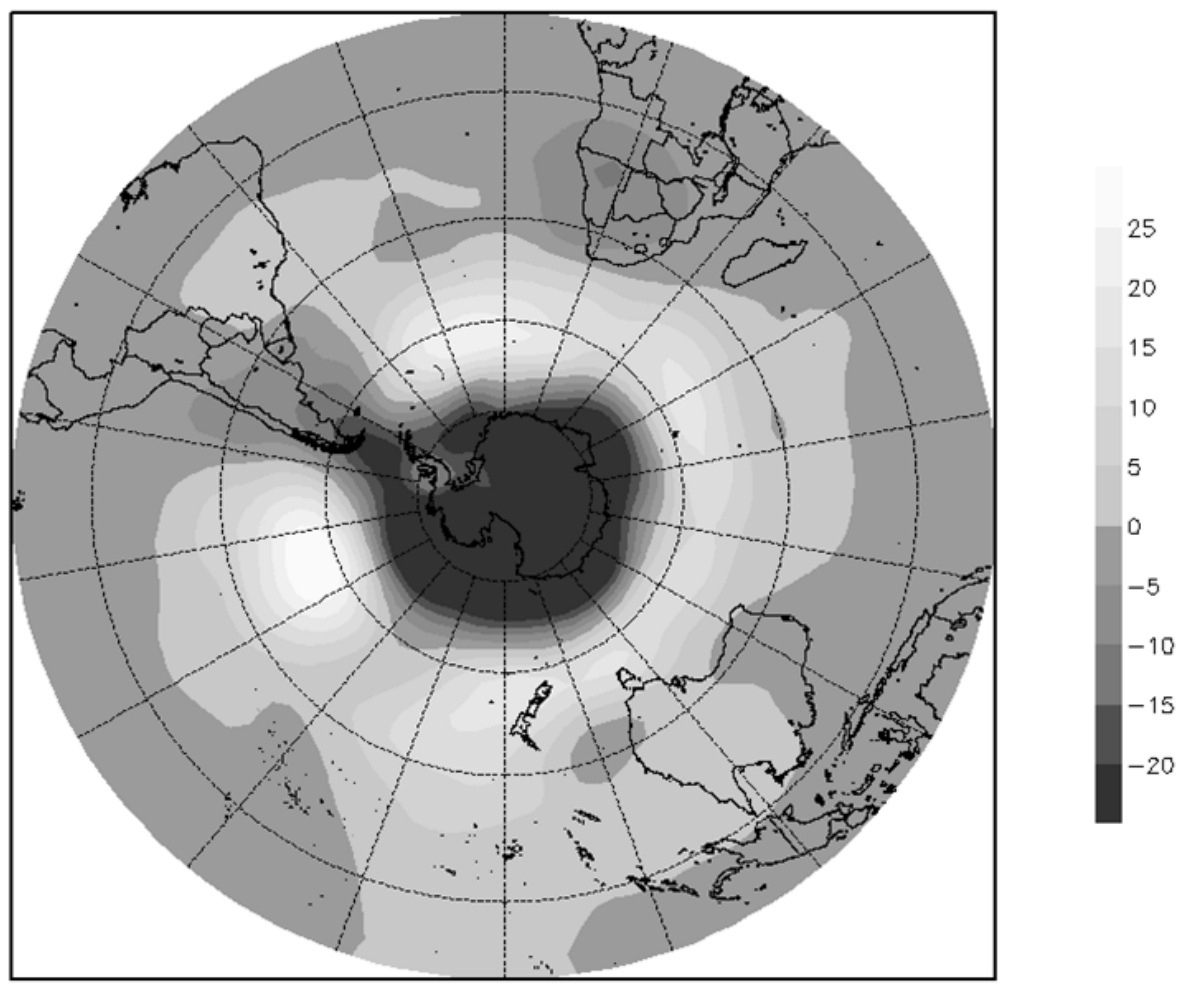

Fig. 11 Difference in 500 hPa geopotential heights (units: $\mathrm{m}$ ) for 1995-2002 compared to the remaining years of the 1979-2011 period.

The positive tropospheric anomalies in the southern African sector in the mid-latitudes are reflected across the SH mid-latitudes, indicating a positive SAM relative to the rest of the period. This supports the finding that the rainfall over eastern-southern Africa is positively correlated to the SAM (Gillett et al. 2006). The positive phase of the SAM is further also associated with a southward positioning of the mid-latitude Jet stream (Limpasuvan and Hartmann 2000), noticed also specifically towards the east of southern Africa during this period (Fig. 6).

Considering now the period 1948 to 2011, there are indications that similar large-scale features were associated with multi-year wetter periods. These periods were also characterized by more frequent occurrences of tropical cyclones responsible for extensive rainfall over the Limpopo River Basin (Malherbe et al. 2012). The anomalies over the African and New Zealand sectors (Fig. 11) are of particular interest. In the region of New Zealand the 1995-2002 positive anomalies in geopotential height over and to the east of the country relative to the full 1979-2011 period are, in correspondence to Tyson et al. (1997), more closely associated with the bi-decadal retreat of the Franz Jozeph Glacier. These authors also indicated the anomalies surrounding southern Africa (Fig. 11) to be associated with wetter conditions over much of the subcontinent. Tyson et al. (1997) further indicated that these multi-year anomalies recurred together on bi-decadal time scale throughout the $20^{\text {th }}$ century up to 1996 and could be related to changes in the amplitude and position of troughs and ridges 
of SH standing wave 3. The present study shows evidence that this oscillation of anomalies has subsequently persisted until 2012. The glacial advances/accumulation of the Tasmanian Glacier, located relatively close to the Franz Joseph Glacier, has subsequently been shown to have a negative association with the SAM (Purdie et al. 2011) while Gillett et al. (2006) showed these southern areas of New Zealand to be warmer and drier when the SAM is positive. Indications that the variation in JFM rainfall over the Limpopo River Basin varies on 18-20 year time scale with the SAM will therefore be considered in this paper.

During the 1979-2011 period the most recent peak in the bi-decadal rainfall cycle in the Limpopo region is associated with an anticyclonic anomaly to the east of southern Africa. This is detected in the zonal wind anomaly in that region with stronger westerlies towards the south of $45^{\circ} \mathrm{S}$ and anomalously easterly flow towards the north of $45^{\circ} \mathrm{S}$. On hemispheric scale, this is part of a tendency for anticyclonic anomalies over the mid-latitudes, associated with a positive SAM. Three features of the climate system regionally and on hemispheric scale, which have been considered earlier for the 1979-2011 period, are now considered for the entire period of 1948-2011:

- The geopotential height anomaly at $250 \mathrm{hPa}$ east of southern Africa: (30-70 ${ }^{\circ}, 45-$ $\left.25^{\circ} \mathrm{S}\right)$

- Difference in normalized zonal flow throughout the 700-300 hPa column $\left(30-70^{\circ} \mathrm{E}\right.$ : $45-15^{\circ} \mathrm{S}$ minus $55-45^{\circ} \mathrm{S}$ ). Positive values are associated with easterly anomalies towards the north and westerly anomalies towards the south, associated with anticyclonic anomalies throughout the 700-250 hPa column;

- Southern Annular Mode: Difference between normalized height anomalies at $850 \mathrm{hPa}$ between $40^{\circ} \mathrm{S}$ and $65^{\circ} \mathrm{S}$.

The positive trend in the SAM in reanalysis data is a well-known feature (Marshall 2003). Positive linear trends revealed by each of the three time series (listed above) are removed for time series analysis by subtracting the first order polynomial regression equation fitted to each time series. Fig. 12 shows the time series of the variation in the SAM and the relative strength of the anticyclone to the east of southern Africa as well as the associated anticyclonic flow anomaly throughout the troposphere, calculated as the difference in normalized tropospheric flow (30-70 ${ }^{\circ} \mathrm{E}$ : $45-15^{\circ} \mathrm{S}$ minus $55-45^{\circ} \mathrm{S}$ ) from $700 \mathrm{hPa}$ to $300 \mathrm{hPa}$. Rainfall over the region from the continuous dataset for the 6 stations (Fig. 1) is also shown. 


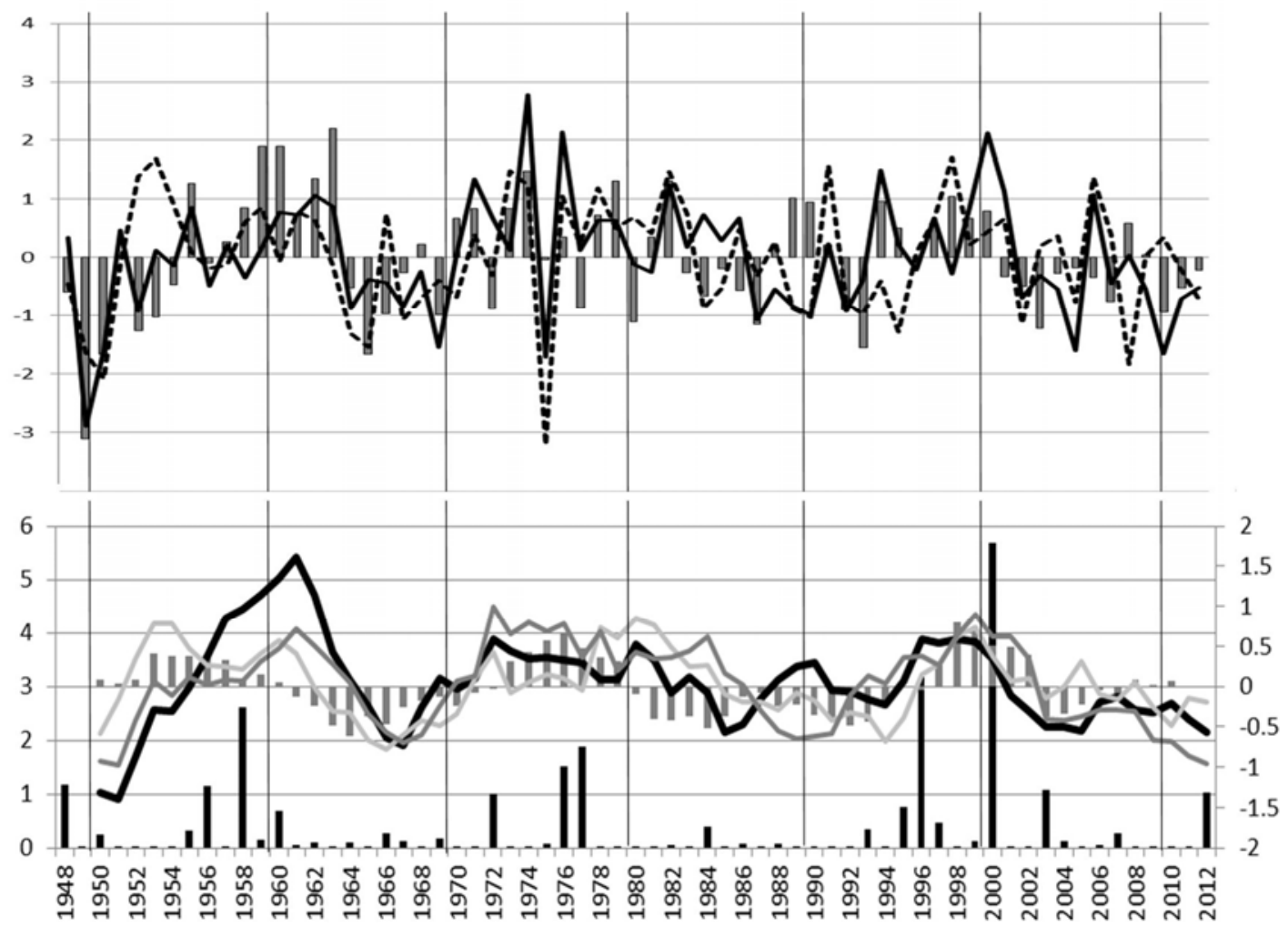

Fig. 12 Top: Detrended time series of the SAM (grey bars), normalized geopotential height anomaly (30$70^{\circ} \mathrm{E}, 45-25^{\circ} \mathrm{S}$, solid line) and normalized zonal flow anomaly throughout 700 to $300 \mathrm{hPa}\left(30-70^{\circ} \mathrm{E}: 45-15^{\circ} \mathrm{S}\right.$ minus 55-45 ${ }^{\circ}$, broken line) for the 1948-2012 period. Bottom: 5-year filtered SAM (black line, secondary yaxis), normalized geopotential height anomaly at $250 \mathrm{hPa}$ (dark grey line, secondary y-axis) and normalized zonal flow anomaly throughout 700 to $300 \mathrm{hPa}$ (light grey line, secondary y-axis), 5-year filtered normalized total seasonal rainfall (grey bars, secondary y-axis) at all stations in the area of interest (Fig. 1) as well as average total rainfall per year contributed by tropical systems from the SWIO (black bars, primary y-axis, units: mm) over stations (dark circles in Fig. 1) in the Limpopo River Basin.

Fig. 12 shows the positive association between the SAM and a deep anticyclonic anomaly to the east of southern Africa. This anomaly is associated with multi-year periods with enhanced late summer rainfall and also enhanced rainfall contributed by tropical systems from the SWIO as also indicated in Fig. 12. Three multi-year periods of anomalously positive SAM and associated regional circulation features with related above-normal rainfall are centred around 1958, 1976 and 1997, coinciding with the maxima within the bi-decadal rainfall cycle (Dyer and Tyson 1977). Also, from reconstructed SAM indices spanning 53 and 119 years, Yuan and Yonekura (2011) report significant peaks at 16 and 18 years for autumn and at 9 years for summer - both these seasons are considered partially in the JFM time series. The negative association of multi-year rainfall over the eastern parts of southern Africa with glaciation over southern New Zealand (Tyson et al. 1997) can therefore also be attributed to this variation in the $\mathrm{SH}$, as a negative correlation between net accumulation of glaciers in that region and the SAM exists (Purdie et al. 2011). The correlation between the three time series in the southern African region in Fig. 12 is significant (Table 1). 
Table 1 Correlation between the SAM, anticyclonic geopotential height anomaly towards the east of southern Africa $\left(30-70^{\circ} \mathrm{E}, 45-25^{\circ} \mathrm{S}\right)$ and the anticyclonic zonal flow anomaly (difference in normalized zonal flow throughout the $700-300 \mathrm{hPa}$ column $\left(30-70^{\circ} \mathrm{E}: 45-15^{\circ} \mathrm{S}\right.$ minus $\left.55-45^{\circ} \mathrm{S}\right)$. Significance above the $90 \%$ and $95 \%$ levels of confidence is indicated by single and double asterisks, respectively. The period 1948-2011 is considered.

\begin{tabular}{|l|l|l|l|}
\hline & SAM & High & Zonal Wind \\
\hline SAM & 1 & $0.29^{*}$ & $0.59^{* *}$ \\
\hline High & & 1 & $0.5^{* *}$ \\
\hline Zonal Wind & & & 1 \\
\hline
\end{tabular}

The significant correlations indicated in Table 1 support previous findings over the SWIO and southern African region. The anticyclonic anomaly throughout the troposphere towards the east of southern Africa is associated with above-normal SSTs over this part of the Indian Ocean (Jury and Nkosi 2000), which therefore also have a positive correlation with rainfall over southern Africa (Reason and Mulenga 1999). These positive SST anomalies, when associated with a positive South Indian Ocean subtropical dipole event, are further also suggested to be associated with the SH standing wave pattern and SAM (Hermes and Reason 2005). While the SAM influences the ENSO teleconnection towards high latitudes (Fogt et al. 2011), the correlation between the SAM and anticyclonic anomaly to the east of southern Africa is further evidence for modulation of potential regional responses to ENSO as part of large scale hemispheric anomalies. The correlation between the SAM calculated at $850 \mathrm{hPa}$ and the $250 \mathrm{hPa}$ height and 700-500 hPa flow anomaly in the southern African region is shown in Fig. 13. These variables have all been considered earlier for the 1979-2011 period. Also shown is the result of a Fourier analysis performed on the 5-year moving average JFM rainfall, JFM SAM and JFM SOI for the period 1948-2011. 

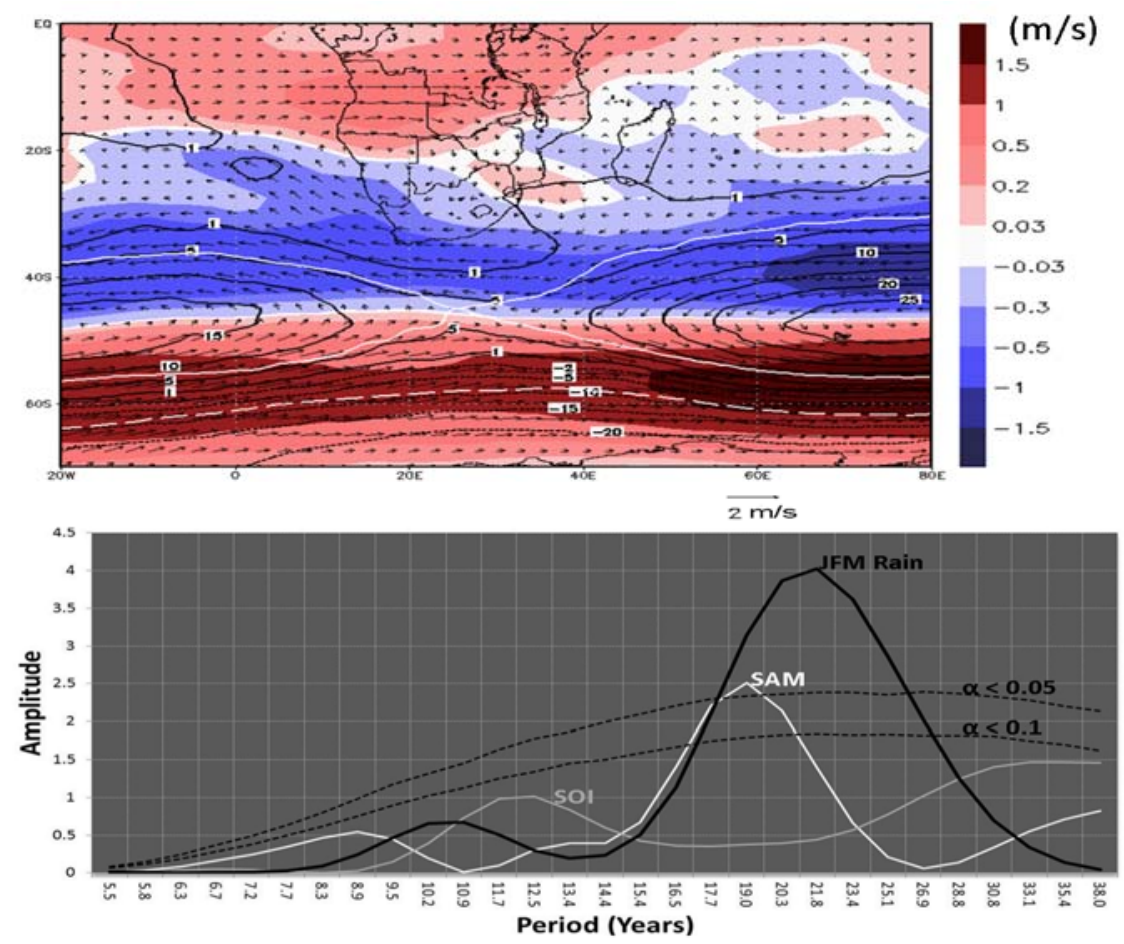

Fig. 13 The change (top) in JFM $250 \mathrm{hPa}$ height (contours, units: m) and 500-700 hPa flow anomaly vectors (scale shown), with U-component shaded (red - positive, blue - negative, units: $\mathrm{ms}^{-1}$ ), per unit SAM increase. Areas where grid points indicate a local significant correlation with the SAM exceeding the 95\% level of confidence is indicated by the white solid and broken lines for positive and negative correlations respectively. The period 1948-2011 is considered. The Periodogram (bottom) is the result of a Fourier analysis over the same period based on the 5-year average of: the SAM (black line, primary axis), normalized SOI (grey line) and normalized rainfall (white line) at the stations in Fig. 1. Broken black lines are the $\mathbf{9 5 \%}$ and $90 \%$ significance levels calculated for all three time series.

The significant positive correlation between the SAM calculated at $850 \mathrm{hPa}$ and the $250 \mathrm{hPa}$ height anomaly around $40^{\circ} \mathrm{S}$ is to be expected. More importantly though is the relatively large positive correlation towards $60^{\circ} \mathrm{E}$ as well as the large extent northward over the SWIO of these positive anomalies. Steering flow trends are easterly throughout most of the region towards the north of $45^{\circ} \mathrm{S}$. To the north of this region of anomalously easterly flow, the circulation becomes more cyclonic over the northern parts of Namibia (see " $C$ " in Fig. 13). These trends closely resemble the anomalies observed during the 1995-2002 period relative to 1979-2011 (Fig. 5). The Fourier analysis further indicate that (only) the 5-year moving average SAM and JFM rainfall time series both display significant peaks at the $\sim 20$-year period.

Fig. 14 is a summary of regional $250 \mathrm{hPa}$ height and 700-500 hPa steering flow anomalies over the southern African region from $70^{\circ} \mathrm{S}$ to $10^{\circ} \mathrm{S}$ also for the entire 1948-2011 period. Data are subdivided into 9 or 10-year periods, staying with the 18-20 year Dyer-Tyson cycle, supported also by the findings in this paper (Fig. 12, 13). While supporting the result of the Fourier analysis (Fig. 13), it provides further insight into the bi-decadal variability in the SAM and regional anticyclonic anomaly shown in Fig. 12. 


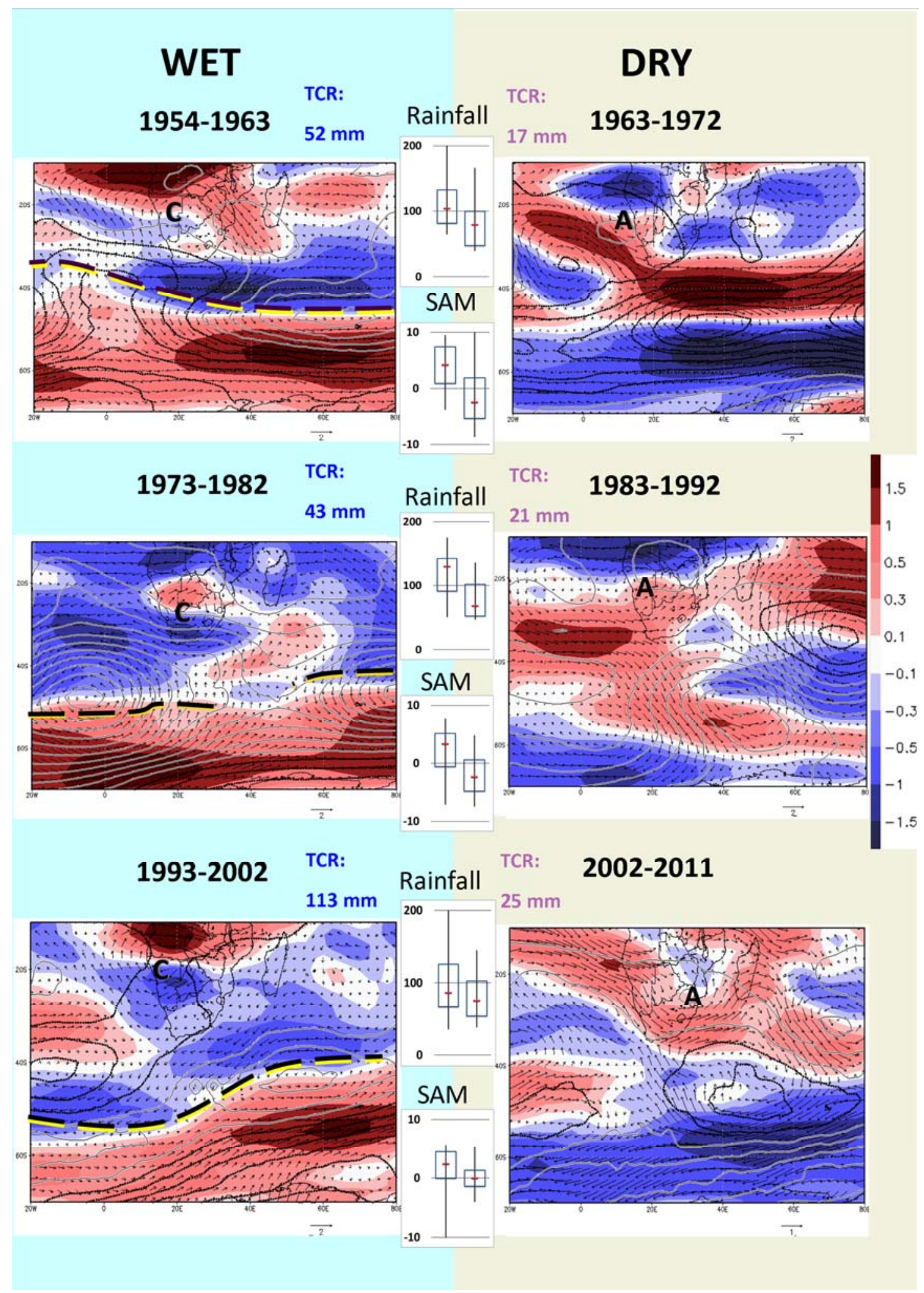

Fig. 14 500-700 hPa steering flow anomaly vectors (scale in $\mathrm{ms}^{-1}$ shown for each map) with U-component shaded (red - positive, blue - negative, units: $\mathrm{ms}^{-1}$ ), and $250 \mathrm{hPa}$ height anomalies (contours) for alternating wet (left) and dry (right) multi-year epochs as indicated. Contour intervals are $5 \mathrm{~m}$; dark (light) contours are for negative (positive) anomalies. The positions of prominent ridges at $850 \mathrm{hPa}$ are also indicated (broken black/yellow lines). Inter-quartile ranges for rainfall (units: \% of average during JFM) as average for all 8 stations in Fig. 1 and the SAM are indicated per epoch for comparison in box plots. The average annual rainfall contributed by tropical systems (TCR, units: $\mathrm{mm}$ ) from the SWIO calculated as an average for the eastern stations (dark circles in Fig. 1) is also indicated per epoch. 
Fig. 14 shows that low frequency, decadal-scale circulation features over the southern African region have alternated between patterns conducive to wet conditions (and increased rainfall contributed by tropical systems from the SWIO) and patterns conducive to drier conditions (with less rain contributed by tropical systems from the SWIO). The wet patterns (left hand side of Fig. 14) resemble the correlation map (Fig 13) indicative therefore of features more strongly associated with a positive SAM during JFM. This is also indicated by the interquartile ranges of the SAM for each epoch, as shown in the box plots in Fig. 14. Most noteworthy is the dominance of westerly anomalies in steering flow towards the south of $40^{\circ} \mathrm{S}$ and strengthened easterly anomalies to the north of $40^{\circ} \mathrm{S}$ during the wet epochs. These are reversed during the dry epochs. Other features of the alternating near-decadal epochs include for wet (dry) conditions:

- Cyclonic (anticyclonic) flow anomalies dominating over the subcontinent to the north of the anomalously easterly (westerly) flow - indicated with "C" (cyclonic) or "A" (anticyclonic);

- Large areas of positive (negative) geopotential height anomalies throughout the troposphere centered near $40^{\circ} \mathrm{S}$, between the anomalously westerly (easterly) steering flow to the south and easterly (westerly) flow towards the north.

Considering the steering flow and $250 \mathrm{hPa}$ height anomalies towards the east of southern Africa near $40^{\circ} \mathrm{S}$, the wet epochs have always been dominated by deep anticyclonic anomalies and replaced by cyclonic anomalies during the dry epochs. Positive anomalies in this region are also associated with the movement of tropical cyclones and depressions into the Limpopo River Basin (Fig. 2 and 3) and therefore further explain the larger contribution to rainfall (Fig. 4 and "TCR" in Fig.14) by these systems during the wet subperiods.

\section{Conclusions}

Several tropospheric anomalies were responsible for higher rainfall and also a larger contribution to rainfall by tropical cyclones and depressions over the Limpopo River Basin during the 1995-2002 period. These circulation anomalies are also associated with ENSO cold events and positive SAM. The main feature of this wet period is a broadening of the Hadley Cell with a deep anticyclonic circulation anomaly (at $40^{\circ} \mathrm{S}$ ) towards the east of the subcontinent. This feature has been shown to be associated with higher tropical cyclone activity in the SWIO basin (Jury 1993, Jury et al. 1999) and has the following consequences related to tropical systems from the SWIO:

- Enhanced easterly steering flow directing tropical systems towards southern Africa and also responsible for further inland penetration - related also with higher landfall risk (e.g. Vitart et al. 2003);

- Increased moisture content of the lower to middle troposphere towards the southern parts of southern Africa due to low-level convergence over the region and stronger subtropical easterlies - increasing the tropospheric potential for tropical systems moving into the subcontinent to be sustained (e.g. Mulenga et al. 2003);

- Enhanced dynamic potential (negative vorticity and relatively smaller vertical wind shear) for the development of tropical systems over the SWIO as well as over the southern African subcontinent (e.g. Vitart et al. 1999); 
- A southward shift in both the upper air Jet stream and upper air troughs east of the subcontinent (west wind trough formation east of South Africa interacts with the vorticity field (Becker et al. 2010) and steering flow of tropical cyclones in the SWIO, thereby inhibiting the westward trajectory towards and into the Limpopo River Basin).

Conditions become favorable for above-normal rainfall over much of the subcontinent as the Angola Low strengthens (Tyson 1981, Cook et al. 2004). This happens in a band of enhanced negative vorticity and low-level convergence on the northern edge of stronger subtropical easterlies with increased moisture advection over the subtropical subcontinent. The result is that the period associated with above-average rainfall as identified by the Dyer-Tyson cycle in the region is also characterized by an increase in tropical cyclones and depressions penetrating the subcontinent (Malherbe et al. 2012). The implications are that more tropical cyclones and depressions penetrate the subcontinent during wet summers in multi-year periods with above-normal rainfall when soils are saturated and reservoirs full, enhancing the probability of major flood events in the Limpopo River Basin such as happened in 1996 and 2000.

Since 1948, three wet epochs over parts of southern Africa (1954-1963, 1973-1982 and 19932002) were associated with the anomalously anticyclonic circulation east of the subcontinent (throughout the troposphere) and a lower level cyclonic anomaly over much of the subcontinent. The anticyclonic anomaly has been shown to be related to a bi-decadal cycle in the SAM for JFM. This anomaly may contribute to observed ENSO-like decadal to multidecadal variability (Reason and Rouault 2002) in the region. The SAM and associated regional anticyclonic anomaly have varied in tandem since 1948 (the period for which data are available). The regional circulation anomaly provides further insight into the bi-decadal Dyer-Tyson rainfall cycle over parts of southern Africa and associated variation in influence of tropical systems from the SWIO over the Limpopo River Basin (Malherbe et al. 2012). Its association with the SAM also explains the inverse relationship between multi-year wet periods over large parts of the southern African summer rainfall region and glacial advances over southern New Zealand noted earlier (Tyson et al. 1997), a feature that has occurred on an 18-20-year time scale since at least the beginning of the $20^{\text {th }}$ century. It is therefore concluded that the bi-decadal rainfall cycle can be attributed to the low-frequency variation in pressure distribution and (zonal) wind anomalies over much of the mid- and high latitudes of the SH. This is represented by an oscillation in the SAM during JFM with similar periodicity. The associated variation in the Southwest Indian Ocean implies a possible mechanism for an altered regional response to or expression of ENSO, with both warm and cold events being wetter (drier) during the wet (dry) part of the bi-decadal oscillation.

\section{Acknowledgements}

The authors would like to acknowledge the Water Research Commission (WRC Project No. K5/1847) in South Africa, the Agricultural Research Council (Project No. GW 50/053) and ACCESS (Applied Centre for Climate and Earth System Science) for supporting this research. ACCESS is a South African Centre of Excellence of the Department of Science and Technology. The contributions of two anonymous reviewers are gratefully acknowledged. Editing by Dr TP Fyfield at the ARC is also much appreciated. 


\section{References}

Becker S, Büker ML, Matyas CJ and Rohli RV (2010) Assessing links between atmospheric vorticity patterns and directional changes in hurricane tracks. Theor Appl Climatol 102:397392.

Camargo SJ, Emanuel KA and Sobel AH (2007) Use of a genesis potential index to diagnose ENSO effects on tropical cyclone genesis. J Clim 20(19):4819-4834. doi: 10.1175/JCLI4282.1.

Chan JCL (1985) Identification of the steering flow for tropical cyclone motion using objectively-analyzed wind fields. Mon Weather Rev 113:106-116.

Chu P-S (2002) Large-scale circulation features associated with decadal variations of tropical cyclone activity over the Central North Pacific. J Climate 15:2678-2689.

Cook KH (2000) A Southern Hemisphere wave response to ENSO with implications for Southern Africa Precipitation. J Atmos Sci 58:2146-2162.

Cook C, Reason CJC and Hewitson BC (2004) Wet and dry spells within particularly wet and dry summers in the South African summer rainfall region. Climate Res 26:17-31.

Cram P, Fendrick, AM, Inadomi J, Cowen ME, Carpenter D and Vijan S (2003) The impact of a celebrity promotional campaign on the use of colon cancer screening: the Catie Couric effect. Arch Intern Med 163:1601-1605.

Crimp SJ and Mason SJ (1999) The Extreme Precipitation Event of 11 to 16 February 1996 over South Africa. Meteorol Atmos Phys 70:29-42. doi: 10.1007/s007030050023.

D'Abreton PC and Lindesay JA (1993) Water vapour transport over Southern Africa during wet and dry early and late summer months. Int $\mathrm{J}$ Climatol 13:151-170. doi: 10.1002/joc.3370130203.

Dyer TGJ and Tyson PD (1977) Estimating above and below normal rainfall periods over South Africa, 1972-2000. J Appl Meteorol 16:145-147. doi: 10.1175/15200450(1977)016<0145:EAABNR>2.0.CO.

Dyson LL and van Heerden J (2002) A model for the identification of tropical weather systems over South Africa. Water SA 28:249-258. ISSN 0378-4738.

Fogt RL, Bromwich DH and Hines KM (2011) Understanding the SAM influence on the South Pacific ENSO teleconnection. Clim Dynam 36: 1555-1576.

Gershunov A and Barnett TP (1998) Interdecadal Modulation of ENSO Teleconnections. Bull Amer Meteor Soc 79:2715-2725. doi: 10.1175/15200477(1998)079<2715:IMOET>2.0.CO;2.

Gillett NP, Kell TD and Jones PD (2006) Regional climate impacts of the Southern Annular Mode. Geophys Res Lett 33:L23704.

Goldenberg SB, Landsea CW, Mesta-Nunez AM and Gray WM (2001) The recent increase in Atlantic hurricane activity: causes and implications. Science 293:474-479. doi: 10.1126/science.1060040. 
Gong D and Wang S (1999) Definition of Antarctic oscillation index, Geophys Res Lett 26(4):459-462. doi: 10.1029/1999GL900003.

Gong T, Feldstein SB and Luo D (2010) The Impact of ENSO on Wave Breaking and Southern Annular Mode Events. J Atmos Sci 67: 2854-2870.

Gray WM (1984) Atlantic seasonal hurricane frequency. Part I: El Niño and $30 \mathrm{mb}$ quasibiennial oscillation influences. Mon Weather Rev 112:1649-1668.

Gray WM (1988) Environmental influences on tropical cyclones. Aust Meteorol Mag 36:127139.

L'Heureux M, David L and Thompson WJ (2006) Observed Relationships between the El Niño-Southern Oscillation and the Extratropical Zonal-Mean Circulation. J Climate 19: 276287.

Hermes JC and Reason CJC (2005) Ocean model diagnosis of interannual coevolving SST variability in the South Indian and South Atlantic oceans. J. Climate 18:2864-2882.

Hurrell JW and van Loon H (1994) A modulation of the atmospheric annual cycle in the Southern Hemisphere. Tellus 46A:325-338.

Hines KM, Bromwich DH and Marshall GJ (2000) Artificial surface pressure trends in the NCEP-NCAR Reanalysis over the Southern Ocean and Antarctica. J Climate 13:3940-3952.

Ho M, Kiem AS and Verdon-Kidd DC (2012) The Southern Annular Mode: a comparison of indices. Hydrol Earth Syst Sci 8:7461-7498. doi: 10.5194/hessd-8-7461-2011.

Hofmeyr WL and Gouws V (1964) A statistical and synoptic analysis of wet and dry conditions in the northwestern Transvaal. Notos 13:37-48.

Holland GJ (1982) Tropical cyclone motion: environmental interaction plus a beta effect. J Atmos Sci 40:328-342.

Holland GJ (1984) Tropical cyclone motion: A comparison of theory and observation. J Atmos Sci 41:68-75.

Jury MR (1993) A preliminary study of climatological associations and characteristics of tropical cyclones in the SW Indian Ocean. Meteorol Atmos Phys 51:101-115. doi: 10.1007/BF01080882.

Jury MR (1996) Regional teleconnection patterns associated with summer rainfall over South Africa, Namibia and Zimbabwe. Int J Climatol 16:135-153. doi: 10.1002/(SICI)10970088(199602)16:2<135:AID-JOC4>3.0.CO;2-7.

Jury MR and Nkosi SE (2000) Easterly flow in the tropical Indian Ocean and climate variability over south-east Africa. Water SA 26:147-152.

Jury MR and Pathack B (1991) A study of climate and weather variability over the tropical southwest Indian Ocean. Meteorol Atmos Phys 47:37-48. doi: 10.1007/BF01025825.

Jury MR, Pathack B and Parker B (1999) Climatic determinants and statistical prediction of tropical cyclone days in the Southwest Indian Ocean. J Clim 12: 1738-1746. 
Kalnay E, Kanamitsu M, Kistler, R, Collins W, Deaven D, Gandin L, Iredell M, Saha S, White G, Woollen J, Zhu Y, Leetmaa A, Reynolds R, Chelliah M, Ebisuzaki W, Higgins W, Janowiak J, Mo KC, Ropelewski C, Wang J, Jenne R and Joseph D (1996) The NCEP/NCAR 40-year reanalysis project. B Am Meteorol Soc 77:437-457. doi: 10.1175/15200477(1996)077<0437: TNYRP>2.0.CO.

Kanamitsu M, Kistler RE and Reynolds RW (1997) NCEP/NCAR Reanalysis and the use of satellite. Adv Space Res 19(3):481-489.

Kohonen T (2001) Self-Organising Maps, $3^{\text {rd }}$ edition. Springer-Verlag, Berlin Heidleberg New York.

Kohonen T, Hynninen J, Kangas J and Laaksonen J (1996) SOM_PAK: The Self-Organizing Map Program Package. Technical Report A31. Laboratory of Computer and Information Science, Helsinki University of Technology, Finland. 24 pp.

Kruger AC (1999) The influence of the decadal-scale variability of summer rainfall on the impact of El Niño and La Niña events in South Africa. Int J Climatol 19:59-68.

Kubota H and Chan JCL (2009) Interdecadal variability of tropical cyclone landfall in the Philippines from 1902 to 2005. Geophys Res Lett 36:L12802. doi: 10.1029/2009GL038108.

Lanzante JR (1996) Resistant, robust and non-parametric techniques for the analysis of climate data: theory and examples, including applications to historical radiosonde station data. Int J Climatol 16:1197-1226.

L'Heureux ML, Thompson DWJ (2006) Observed Relationships between the El NiñoSouthern Oscillation and the Extratropical Zonal-Mean Circulation. J Climate 19:276-287. doi: 10.1175/JCLI3617.1

Limpasuvan V and Hartmann DL (2000) Wave-maintained annular modes of climate variability. J Climate 13(24):4414-4429.

Liu KS and Chan JCL (2008) Interdecadal Variability of Western North Pacific Tropical Cyclone Tracks. J Climate 21:4464-4476.

Malherbe J, Engelbrecht FA, Landman WA and Engelbrecht CJ (2012) Tropical systems from the southwest Indian Ocean making landfall over the Limpopo River Basin, southern Africa: a historical perspective. Int J Climatol 32:1018-1032. doi: 10.1002/joc.2320.

Marshall GJ (2003) Trends in the Southern Annular Mode from observations and Reanalysis. J Climate 16:4134-4143.

Mason SJ and Jury MR (1997) Climatic variability and change over southern Africa: a reflection on underlying processes. Prog Phys Geog 21:23-50.

Matarira CH and Jury MR (1992) Contrasting meteorological structure of intra-seasonal wet and dry spells in Zimbabwe. Int J Climatol 12:165-176. doi: 10.1002/joc.3370120205.

Matsuura T, Yumoto M and Iizuka S (2003) A mechanism of interdecadal variability of tropical cyclone activity over the western North Pacific. Clim Dynam 21:105-117.

Miron O and Tyson PD (1984) Wet and dry conditions and pressure anomaly fields over South Africa and the adjacent oceans, 1963-1979. Mon Weather Rev 112:2127-2132. 
Mulenga HM, Rouault M and Reason CJC (2003) Dry summers over northeastern South Africa and associated circulation anomalies. Climate Res 25:29-41.

Nicholson SE and Kim J (1997) The relationship of El Niño-Southern Oscillation to African Rainfall. Int J Climatol 17:117-135.

NOAA Web Page (2012)

http://www.cpc.ncep.noaa.gov/products/analysis_monitoring/ensostuff/ensoyears.shtml.

Pezza AB and Ambrizzi T (2003) Variability of Southern Hemisphere cyclone and anticyclone behavior: Further analysis. J Climate 16:1075-1083.

Pohl B, Fauchereau N, Reason CJC and Rouault M (2010) Relationships between the Antarctic Oscillation, the Madden-Julian Oscillation, and ENSO, and Consequences for Rainfall Analysis. J Climate 23:238-254. doi: 10.1175/2009JCLI2443.1.

Preston-Whyte RA and Tyson PD (2000) The atmosphere and weather of southern Africa. Oxford University Press: Southern Africa.

Purdie H, Mackintosh A, Lawson W, Anderson B, Morgenstern U, Chinn T and Mayewski P (2011) Interannual variability in net accumulation on Tasman glacier and its relationship with climate. Global Planet Change 77:142-152.

Reason CJC (2002) Sensitivity of the southern African circulation to dipole sea-surface temperature patterns in the South Indian Ocean. Int J Climatol 22:277-393.

Reason CJC and Keibel A (2004) Tropical Cyclone Eline and its unusual penetration over the Southern African mainland. Weather Forecast 19:789-805. doi: 10.1175/15200434(2004)019.

Reason CJC and Rouault M (2002) ENSO-like decadal variability and South African rainfall. Geophys Res Lett 29(13):1638. doi: 10.1029/2002GL014663.

Reason CJC and Rouault M (2005) Links between the Antarctic Oscillation and winter rainfall over western South Africa. Geophys Res Lett 32:L07705. doi:10.1029/2005GL022419.

Reason CJC, Hachigonta S and Phaladi RF (2005) Interannual variability in rainy season characteristics over the Limpopo region of southern Africa. Int J Climatol 25:1835-1853. doi: 10.1002/joc.1228.

Reason CJC, Allan RJ, Lindesay JA and Ansell TJ (2000) ENSO and climatic signals across the Indian Ocean basin in the global context: Part I, Interannual composite patterns. Int $\mathrm{J}$ Climatol 20:1285-1327.

Reason CJC and Mulenga HM (1999) Relationships between South African rainfall and SST anomalies in the south west Indian Ocean. Int J Climatol 19:1651-1673.

Richard Y, Trzaska S, Roucou P and Rouault M (2000) Modification of the southern African rainfall variability/|ENSO relationship since the late 1960s. Clim Dynam 16:883-895.

Richard Y, Fauchereau N, Poccard I, Rouault M and Trzaska S (2001) 20 $0^{\text {th }}$ Century droughts in southern Africa: Spatial and temporal variability, teleconnections with oceanic and atmospheric conditions. Int J Climatol 21:873-885. doi: 10.1002/joc.656. 
Ropelewski CF and Halpert MS (1987) Global and regional precipitation patterns associated with the El Niño/Southern Oscillation. Mon Weather Rev 115:1606-1626.

Sturaro G (2003) A closer look at the climatological discontinuities present in the NCEP/NCAR reanalysis temperature due to the introduction of satellite data. Clim Dynam 21:309-316.

Taylor WA (2000) Change-point analysis: a powerful new tool for detecting changes. preprint, available at http://www. variation.com/cpa/tech/changepoint.html.

Tennant WJ (2004) Considerations when using pre-1979 NCEP/NCAR reanalysis in the southern hemisphere. Geophys Res Lett 31:L11112. doi: 10/1029/2004GLO197501.

Trenberth KE (1980) Planetary waves at $500 \mathrm{mb}$ in the Southern Hemisphere. Mon Weather Rev 108:1378-1389.

Tyson PD (1981) Atmospheric circulation variations and the occurrence of extended wet and dry spells over southern Africa. J Climatol 1:115-130.

Tyson PD, Cooper GRJ and McCarthy TS (2002) Millennial to multi-decadal variability in the climate of southern Africa. Int J Climatol 22:1105-1117. doi: 10.1002/joc.787.

Tyson PD, Sturman AP, Fitzharris BB, Mason SJ and Owens IF (1997) Circulation changes and teleconnections between glacial advances on the west coast of New Zealand and extended spells of drought years in South Africa. Int J Climatol 17:1499-1512. doi: 10.1002/(SICI)1097-0088(19971130)17:14<1499::AID-JOC207>3.0.CO;2-O.

Vitart F, Anderson A and Stockdale T (2003) Seasonal forecasting of tropical cyclone landfall over Mozambique. J Climate 16:3932-3945. doi:10.1175/15200442(2003)016<3932:SFOTCL>2.0.CO.

Vitart F, Anderson L and Stern WF (1999) Impact of large-scale circulation on tropical storm frequency, intensity and location, simulated by an ensemble of GCM integrations. J Climate 12:3237-3254. doi: 10.1175/1520-0442(1999)012<3237:IOLSCO>2.0.CO;2.

Washington R and Preston A (2006) Extreme wet years over southern Africa: Role of Indian Ocean sea surface temperatures. J Geophys Res 111:D15104. doi:10.1029/2005JD006724.

Wilks DS (2011) Statistical Methods in the Atmospheric Sciences, Third Edition. Academic Press, Amsterdam.

Yuan X and Yonekura E (2011) Decadal variability in the Southern Hemisphere. J Geophys Res 116:D19115. doi:10.1029/2011JD015673. 